\title{
PARTIAL PURIFICATION AND CHARACTERIZATION OF AN EXTRACELLULAR METALLOPEPTIDASE PRODUCED BY Bacillus amyloliquefaciens FE-K1
}

\author{
Fundagül EREM ${ }^{1,2}$, Mehmet INAN ${ }^{1,3}$, Barçın KARAKAŞ BUDAK ${ }^{1}$, Muharrem CERTEL ${ }^{1 *}$ \\ ${ }^{1}$ Akdeniz University, Faculty of Engineering, Department of Food Engineering, 07059, Antalya, TURKEY \\ ${ }^{2}$ Zonguldak Bulent Ecevit University, Faculty of Engineering, Department of Food Engineering, 67100, Zonguldak, TURKEY \\ ${ }^{3}$ İzmir Biomedicine and Genome Center, 35330, İzmir, TURKEY
}

Cite this article as:

Erem F., Inan M., Karakaş Budak B. \& Certel M. 2020. Partial Purification and Characterization of an Extracellular Metallopeptidase Produced by Bacillus amyloliquefaciens FE-K1. Trakya Univ J Nat Sci, 21(1): 47-61, DOI: 10.23902/trkjnat.647525

Received: 16 November 2019, Accepted: 26 March 2020, Online First: 1 April 2020, Published: 15 April 2020

Edited by:

Mustafa Yamaç

*Corresponding Author:

Muharrem Certel

certel@akdeniz.edu.tr

\section{ORCID ID:}

orcid.org/0000-0002-1901-5590

Key words:

Bacillus amyloliquefaciens FE-K1 Metallopeptidase

Ropey bread

Purification

\begin{abstract}
The aim of this study was to purify and characterize the peptidase of Bacillus amyloliquefaciens (Fukumoto) (strain FE-K1) isolated from ropey bread. Peptidases were purified from crude enzyme solution by affinity chromatography with an efficiency of $25 \%$ and a purification coefficient of 1.53 . The optimum $\mathrm{pH}$ of partially purified peptidase (PPPase) solution was determined as 7.5 and the peptidases retained approximately $90 \%$ of their initial activity in the $\mathrm{pH}$ range $7.0-8.5$ following incubation at $37^{\circ} \mathrm{C}$ for $2 \mathrm{~h}$. The optimum temperature for the PPPase was $60^{\circ} \mathrm{C}$. The approximate molecular weight of the PPPase was determined as $36 \mathrm{kDa}$. Inactivation of the PPPase in the presence of O-FEN and EDTA showed them to be metallopeptidases and $5 \mathrm{mM}$ of $\mathrm{K}^{+1}$ and $5 \mathrm{mM}$ of $\mathrm{Mn}^{+2}$ ions increased the enzyme activity by $4 \%$ and $6.15 \%$, respectively. The presence of $\mathrm{Hg}^{+2}, \mathrm{Fe}^{+3}$ and SDS $(0.1-1.0 \% \mathrm{w} / \mathrm{v})$ caused inactivation whereas the enzyme retained most of its activity in the presence of $0.1-1.0 \%(\mathrm{v} / \mathrm{v})$ Triton X-100, Tween 20 and Tween 80 and 1-20\% (v/v) xylene, ethanol, acetone and acetonitrile. Characterization of the PPPase revealed the enzyme as a neutral serine metallopeptidase compatible with some organic solvents and surfactants.
\end{abstract}

Özet: $\mathrm{Bu}$ çalışmanın amacı, sünmüş ekmeklerden izole edilen Bacillus amyloliquefaciens (Fukumoto) (suş FE-K1) ile elde edilen peptidazı saflaştırmak ve karakterize etmektir. Peptidazlar ham enzim çözeltisinden afinite kromatografisi ile \% 25 verim ve 1,53 saflaştırma katsayısı ile saflaştırılmıștır. Kısmi olarak saflaştırılmış peptidaz (PPPaz) çözeltisinin optimum pH değeri 7,5 olarak tespit edilmiş olup, $\mathrm{pH} 7,5-8,0$ aralığında peptidaz, $37^{\circ} \mathrm{C}$ 'de 2 saat inkübasyonun ardından başlangıç aktivitesini yaklaşı \% 90 oranında korumuştur. PPPaz'ın optimum sıcaklığ $60^{\circ} \mathrm{C}$ 'dir. PPPaz'ın yaklaşık molekül ağırlı̆ı $36 \mathrm{kDa}$ olarak belirlenmiştir. PPPaz'ın O-FEN ve EDTA varlığında inaktive olması, enzimin metallopeptidaz olduğunu göstermiş̧tir. Ayrıca $5 \mathrm{mM} \mathrm{K}{ }^{+1}$ ve 5 $\mathrm{mM} \mathrm{Mn}{ }^{+2}$, enzimin aktivitesini sırasıyla $\% 4$ ve $\% 6,15$ oranında artırmıştır. $\mathrm{Hg}^{+2}, \mathrm{Fe}^{+3}$ ve SDS (\% $0,1-1,0 \mathrm{w} / \mathrm{v})$ varlığ enzimin inaktivasyonuna neden olurken, \% 0,1-1,0 (v/v) Triton X-100, Tween 20 ve Tween 80 ; ve \% 1-20 (v/v) ksilen, etanol, aseton ve asetonitril varlığında enzim aktivitesini büyük ölçüde korumuştur. PPPaz'ın karakterizasyonu, enzimin bazı organik çözücü ve yüzey aktif maddelerle ile uyumlu nötr bir serin metalopeptidaz olduğunu ortaya çıkarmıştır.

\section{Introduction}

Peptidases (EC 3.4) constitute an enzyme group that converts proteins or large polypeptides into smaller peptides or free amino acids by hydrolysing peptide bonds (da Silva 2017). Although generally known as proteases, the Nomenclature Committee of the International Union of Biochemistry and Molecular Biology (NC-IUBMB) recommends using the terms 'peptidase' or 'peptide hydrolase' for any enzyme that hydrolyses peptide bonds (Rawlings et al. 2007).
Peptidases are essential constituents of all life forms on earth, including prokaryotes, fungi, plants and animals, and therefore can be used for industrial purposes when isolated from these organisms (Gupta et al. 2002a, Gupta et al. 2002b). These enzymes sourced almost exclusively from microorganisms have extensive applications in food industry, pharmaceutical industry, detergent industry, bioremediation processes, and leather treatment, among others (Sandhya et al. 2005, Razzaq et al. 2019, Salwan \& Sharma 2019, Thapa et al. 2019). Therefore, many 
researchers pay much of their attentions to these enzymes and are focusing on discovering and developing new peptidases with desired properties.

Microorganisms secrete peptidases to degrade proteins and utilize the degradation products as nutrients for their growth. Degradation is initiated by endopeptidases and is followed by exopeptidases at extra- or intracellular locations for further hydrolysis. A variety of peptidases are produced by microorganisms depending on the species of the producer or the strain. The type and quantity of enzyme produced may vary for different strains of the same species or even the same strain under different cultural conditions (Sandhya et al. 2005, Jisha et al. 2013). Despite the long list of peptidase-producing microorganisms, only a few being considered as potential producers for commercial exploitation are 'generally recognised as safe' (GRAS), non-toxic and non-pathogenic. Of these, strains of Bacillus spp. dominate the industry producing a substantial portion of all extracellular peptidases used. Furthermore, these strains are quick to grow and much is known about their biochemistry, physiology and genetics [especially Bacillus subtilis (Ehrenberg) Cohn], which facilitates further development and greater exploitation of these microorganisms in industrial processes (Waites et al. 2001, Gupta et al. 2002a, Schallmey et al. 2004, Contesini et al. 2018).

Rope is a type of spoilage seen in bread caused by $B$. subtilis as the most common causative agent along with $B$. licheniformis Weigmann, B. megaterium Bary, $B$. pumilus Meyer and Gottheil, and B. cereus Frankland and Frankland. During the baking process, most vegetative forms of bacteria are killed. However, spores can endure the baking process, where the temperature in the centre of the crumb may not rise above $100^{\circ} \mathrm{C}$. Under humid and warm storage conditions the spores germinate and cause rope spoilage (Kirschner \& von Holy 1989, Collins et al. 1991, Volavsek et al. 1992, Thompson et al. 1993). The most apparent change takes place in the centre of the crumb, observed as stickiness and development of putrid odor. Stickness develops as a result of degradation of starch and protein molecules via amylases and peptidases secreted by the germinated bacteria (Kirschner \& von Holy 1989, Voysey 1989, Bailey \& von Holy 1993, Rosenkvist \& Hansen 1995, Ellis et al. 1997, Thompson et al. 1998, Pepe et al. 2003, Erem et al. 2009). Therefore, Bacillus spp. isolated from ropey bread are candidate strains, which may be exploited for industrial peptidase production. The aim of this study was to purify and characterize the peptidase of $B$. amyloliquefaciens FE-K1 previously isolated from ropey wholemeal bread and to evaluate the suitability of the peptidase produced for industrial use based on some of its characteristics.

\section{Materials and Methods}

\section{Microorganism and the growth media}

The bacterial strain used in this study was previously isolated from ropey wholemeal bread (Erem et al. 2009). The gene sequence of the strain was determined with 16S
rRNA by REFGEN (Gene Research and Biotechnology, Ankara, TURKEY), and the strain was identified as B. amyloliquefaciens FE-K1. Nucleotide sequence data for the strain are available in the GenBank databases under the accession number MH045777. Furthermore, B. amyloliquefaciens FE-K1 was verified as a haemolytic (Hbl) and non-haemolytic (Nhe) enterotoxin-negative strain (not published).

The composition of the growth medium (GM1) used for the preparation of preculture was $2 \mathrm{~g} / \mathrm{L}$ of glucose, 10 $\mathrm{g} / \mathrm{L}$ of yeast extract, $1 \mathrm{~g} / \mathrm{L}$ of $\mathrm{KH}_{2} \mathrm{PO}_{4}, 3 \mathrm{~g} / \mathrm{L}$ of $\mathrm{K}_{2} \mathrm{HPO}_{4} .3 \mathrm{H}_{2} \mathrm{O}, 2 \mathrm{~g} / \mathrm{L}$ of $\mathrm{Na}_{2} \mathrm{SO}_{4}$ and $0.1 \mathrm{~g} / \mathrm{L}$ of $\mathrm{MgSO}_{4} .7 \mathrm{H}_{2} \mathrm{O}$. The $\mathrm{pH}$ of $\mathrm{GM} 1$ was 7.2 , but; it was adjusted to 6.62 (Erem et al. 2018) with $6 \mathrm{~N} \mathrm{HCl}$ and $6 \mathrm{~N}$ $\mathrm{NaOH}$ before sterilization and used as the primary peptidase production medium (GM2). Stock culture and inoculum were prepared according to Erem et al. (2018).

\section{Peptidase production}

The cultivation for enzyme production was done with $2.3 \%(\mathrm{v} / \mathrm{v})$ of preculture in flasks containing GM2 at $33.4^{\circ} \mathrm{C}$ and $250 \mathrm{rpm}$ for $7 \mathrm{~h}$. The inoculation rate, temperature, shaking rate, and the time previously determined as optimum levels for enzyme production were used as cultivation parameters (Erem et al. 2018, Erem \& Certel 2018). Cell-free supernatant obtained by centrifugation (at $20000 \times \mathrm{g}, 4^{\circ} \mathrm{C}$ for $15 \mathrm{~min}$ ) was used as the crude enzyme solution (CES).

\section{Peptidase assay}

The peptidase assay was performed according to Cupp-Enyard (2008) with some modifications. After incubation, a clear solution was obtained by centrifugation at $10000 \times g$ and $4^{\circ} \mathrm{C}$ instead of using syringe filters. The peptidase activity of cell-free clear supernatant was assayed at $37^{\circ} \mathrm{C}$ in potassium phosphate buffer $(50 \mathrm{mM}, \mathrm{pH} 7.5)$ by using $0.65 \%(\mathrm{w} / \mathrm{v})$ casein as substrate. One unit of peptidase was equivalent to the amount of enzyme required to release $1 \mathrm{mg}$ of tyrosine $/ \mathrm{mL} / \mathrm{min}$ under standard assay conditions.

\section{Protein content}

The total protein content of the enzyme solution was determined by the method of Bradford (1976) using a Coomassie Plus (Bradford) Assay Kit (Thermo Scientific, Pierce Biotechnology, USA).

\section{Pretreatment of solutions and CES before purification}

All the solutions used in the purification process were prepared with double-distilled water. They were filtered through a $0.22 \mu \mathrm{m}$ filter (PES) and degassed in an ultrasonic water bath (Bandelin Sonorex RK $255 \mathrm{H}$, Germany). CES was filtered through a $0.45 \mu \mathrm{m}$ filter (PES, low protein-binding). Then, $15 \mathrm{~mL}$ of filtered CES was put into an ultrafiltration tube (Vivaspin 20, 10000 MWCO, PES, Sartorious) and centrifuged (at $8000 \times g$, $4^{\circ} \mathrm{C}$ ) until 10-fold volumetric concentration was achieved. Concentrated CES (1.5 mL) was loaded onto a HiTrap desalting column (GE Healthcare, Sweden) for buffer exchange using an Äkta Prime purification system (GE 
Healthcare Life Sciences, Sweden) with a flow rate of 5 $\mathrm{mL} / \mathrm{min}$. Column equilibration and the buffer exchange process were made with $100 \mathrm{mM} 3$-(N-morpholino) propanesulfonic acid [MOPS ( $\mathrm{pH}$ 7.0)]. The effluent from the column was monitored with a UV monitor during the buffer exchange process, and $1 \mathrm{~mL}$ of fractions was collected until the UV peak gave an absorbance of zero. Peptidase analysis was performed on each fraction, and the fractions showing peptidase activity were combined for the main purification.

Purification of the peptidase by affinity
$\frac{\text { chromatography }}{\text { Column and buffer solutions were selected according }}$
to Lauer et al. (2000). Purification was made with the Äkta Prime protein purification system by using $1 \mathrm{~mL}$ of a HiTrap Blue HP column (GE Healthcare, Sweden). After the column was equilibrated with the binding buffer of $100 \mathrm{mM}$ MOPS (pH 7.0), $5 \mathrm{~mL}$ of the sample was loaded onto the column with a flow rate of $1 \mathrm{~mL} / \mathrm{min}$. Then, the column was washed with $10 \mathrm{~mL}$ of the binding buffer. Later, the column was washed with $25 \mathrm{~mL}$ of elution buffer (100 mM MOPS, $1 \mathrm{M} \mathrm{NaCl}, \mathrm{pH}$ 7.0) by using a step gradient. One $\mathrm{mL}$ of fractions collected from the beginning of sample loading until the end of the elution process were tested for peptidase activity. However, peptidase activity analysis of elution fractions was performed after the desalting procedure using a HiTrap desalting column with a buffer solution of potassium phosphate $(50 \mathrm{mM}, \mathrm{pH} 7.5)$. Fractions that showed peptidase activity were used for further analysis.

\section{Electrophoresis and zymography}

SDS-PAGE was carried out by the method described by Laemmli (1970) using $10 \%$ polyacrylamide resolving gels. Staining was done by Coomassie Blue (G-250). Molecular weight markers of 10-200 kDa (Page Ruler Unstained Protein Ladder, Pierce Biotechnology, USA) were used. The gels were scanned with an Odyssey Infrared Imaging System (LICOR, Lincoln, NE, USA).

Zymography was performed by modifying the method of Leber \& Balkwill (1997). Peptidases were separated on SDS-PAGE gels containing $0.08 \%$ casein (w/v) as substrate. After electrophoresis, gels were treated as described by Fernández-Resa et al. (1994). Staining and visualization were the same as for SDS-PAGE gels. SDSPAGE and zymography were also applied to desalted samples of elution fractions.

Determination of optimum $\mathrm{pH}$ value of the enzyme and pH stability

The peptidase activity was analysed at $37^{\circ} \mathrm{C}$ with a substrate of $0.65 \%(\mathrm{w} / \mathrm{v})$ casein prepared in $50 \mathrm{mM}$ of different buffer systems [sodium citrate $(\mathrm{pH} 6)$, potassium phosphate ( $\mathrm{pH} 7.0$ and 7.5), Tris- $\mathrm{HCl}(\mathrm{pH} \mathrm{8.0,} \mathrm{8.5} \mathrm{and}$ 9.0), glycine- $\mathrm{NaOH}$ (pH 10 and 11) and $\mathrm{KCl}-\mathrm{NaOH}(\mathrm{pH}$ 12 and 13)]. After determining the optimum $\mathrm{pH}$ value, all other characterization tests were carried out at this $\mathrm{pH}$ value.
Peptidase solution was mixed with an equal volume of the buffer systems mentioned above and incubated at $37^{\circ} \mathrm{C}$ for the determination of $\mathrm{pH}$ stability. The peptidase activity of these mixtures was measured immediately before and after the incubation ( 2 and $18 \mathrm{~h}$ ). The peptidase activity of the mixtures measured before the incubation was accepted as $100 \%$, and the activity after the incubation was calculated as the activity remaining (\%). The purpose of selecting $37^{\circ} \mathrm{C}$ as the incubation temperature before the activity test is the stability of the enzyme at this temperature.

Determination of optimum temperature of enzyme and temperature stability

The optimum temperature of peptidase was determined by measuring the enzyme activity at a temperature range of $4-70^{\circ} \mathrm{C}$ with a substrate of $0.65 \%$ $(\mathrm{w} / \mathrm{v})$ casein prepared in phosphate buffer $(50 \mathrm{mM}, \mathrm{pH}$ 7.5). After determining the optimum temperature, all other characterizations were carried out at this temperature.

In order to determine the temperature stability of peptidase, peptidase solutions were preincubated at different temperatures between 4 and $70^{\circ} \mathrm{C}$, and during incubation, samples were taken at various time intervals $(10,30,60,90$ and $120 \mathrm{~min})$ to test for peptidase activity. The peptidase activity of non-incubated enzyme solutions was accepted as $100 \%$, and the remaining activity of the incubated enzyme solutions was calculated as a percentage.

\section{Effect of peptidase inhibitors}

Enzyme solutions were mixed with different concentrations of peptidase inhibitors [final concentrations after mixing: (PEP-A: 5, 10, $20 \mu \mathrm{M})$, (E64: 10, 20, $40 \mu \mathrm{M})$, (PMSF, O-FEN, and EDTA: 1, 2, 4 $\mathrm{mM})]$ and incubated at $37^{\circ} \mathrm{C}$ for $30 \mathrm{~min}$. Then, peptidase activity was measured (at $60^{\circ} \mathrm{C}, \mathrm{pH} 7.5$ ), and calculations were made by accepting the activity of inhibitor-free enzyme solutions as $100 \%$.

\section{Effect of metal ions}

Enzyme solutions were mixed with equal volumes of metal ions $\left(\mathrm{BaCl}_{2}, \mathrm{CaCl}_{2}, \mathrm{CoCl}_{2}, \mathrm{CuCl}_{2}, \mathrm{FeCl}_{2}, \mathrm{FeCl}_{3}\right.$, $\mathrm{MgCl}_{2}, \mathrm{HgCl}_{2}, \mathrm{MnCl}_{2}, \mathrm{ZnCl}_{2}, \mathrm{NiCl}_{2}, \mathrm{KCl}$ and $\mathrm{NaCl}$ ) to a final concentration of $0.5,2.0$ and $5 \mathrm{mM}$. Then, they were incubated at $37^{\circ} \mathrm{C}$ for $30 \mathrm{~min}$. Peptidase activity was measured (at $60^{\circ} \mathrm{C}, \mathrm{pH} 7.5$ ), and the activity of enzyme solutions diluted with distilled water $(1: 1)$ and incubated at the same conditions was accepted as $100 \%$. The relative activity of metal ion-containing enzyme solutions was calculated.

\section{Effect of organic solvents and surfactants}

In order to determine the effects of organic solvents [ethanol, acetone, acetonitrile and xylene: 1, 5, $20 \%$ $(\mathrm{v} / \mathrm{v})$ ] and surfactants [Triton X-100 (v/v) and SDS (w/v): 0.1, 0.5, $1.0 \%$; Tween 20 and Tween 80: 0.1, 0.5, $1.0 \%$ $(\mathrm{v} / \mathrm{v})]$ on enzyme activity, enzyme solutions were mixed with these substances to the final concentrations given and 
then incubated at $37^{\circ} \mathrm{C}$ for $30 \mathrm{~min}$. After incubation, the peptidase activity was tested at optimum temperature $\left(60^{\circ} \mathrm{C}\right)$ and $\mathrm{pH}$ (7.5). The activity of substance-free enzyme solutions was accepted as $100 \%$, and the activity of others was calculated relatively.

\section{Statistical evaluation}

Experiments were carried out with duplicate samples and triplicate analysis, and the data given represent mean values \pm standard deviations. Correlation between inhibitor concentration and peptidase activity was determined with Minitab Statistical Software (Version 18, Minitab Inc. USA).

\section{Results and Discussion}

Production of peptidase by B. amyloliquefaciens FE-K1

The optimum culture conditions of $B$. amyloliquefaciens FE-K1 for producing peptidase have previously been determined by using one factor at a time (Erem \& Certel 2018), and response surface methodologies (Erem et al. 2018). Depending on the results of our previous studies, B. amyloliquefaciens FE$\mathrm{K} 1$ peptidase was produced by inoculating $2.3 \%$ (v/v) of preculture into flasks containing the production medium and growth at $33.4^{\circ} \mathrm{C}$ and $250 \mathrm{rpm}$ for $7 \mathrm{~h}$. At the end of the cultivation, the peptidase activity and the protein content of the CES were determined as $40.74 \pm 5.48 \mathrm{U} / \mathrm{mL}$ and $0.12 \pm 0.04 \mathrm{mg} / \mathrm{ml}$, respectively, for three different production batch, which gave the best results among the other batches. After ultrafiltration, the peptidase activity and the protein content of the concentrated CES were found as $233.91 \pm 25.85 \mathrm{U} / \mathrm{mL}$ and $0.57 \pm 0.49 \mathrm{mg} / \mathrm{ml}$, respectively. Each batch was evaluated separately in the chromatographic purification steps.

\section{Purification of peptidase by affinity chromatography}

Bacillus amyloliquefaciens FE-K1 peptidase was purified by two chromatographic steps. Before its application to the columns, the CES $(35.12 \pm 0.16$ $\mathrm{U} / \mathrm{mL}$ ) was concentrated, and the activity increased to $201.83 \pm 2.16 \mathrm{U} / \mathrm{mL}$. Then, the concentrated CES was loaded onto a HiTrap desalting column to exchange the buffer solution. A total of 15 fractions were collected during buffer exchange, and they were analysed for their peptidase activity. As seen in Figure 1a, among the total 15 fractions, peptidase activity was observed only in the first six fractions and, of these fractions, the second $(140.86 \pm 2.36 \mathrm{U} / \mathrm{mL})$ and third $(108.78 \pm 2.95$ $\mathrm{U} / \mathrm{mL}$ ) showed the highest activity. Therefore, it was decided to use a combination of these six fractions, which showed peptidase activity for the main purification step.

Although the primary purpose of the buffer exchange process was to adapt the enzyme solution to the binding buffer (100 mM MOPS, pH 7) used in the affinity chromatography as the initial buffer, this step also provided partial purification of the enzyme. According to Fig. 1a, only the first few fractions had peptidase activity, but UV absorbance values were still high up to the $12^{\text {th }}$ fraction. This implies that there were also proteins in the enzyme solution other than peptidases which can leave the column after the peptidases due to the molecular weight difference. In this context, peptidase could be separated from some smaller peptide/protein molecules and possibly other molecules with the process of buffer exchange.

Changes of some parameters related to purification of the peptidase by the HiTrap Blue HP column are shown in Fig. 1b. It was observed from the UV plot that the absorbance was high during the passage of the sample through the column and at the beginning of the washing process. Shortly after the elution stage started, another peak (fractions 16-18) was observed in the UV plot, an indicator of protein presence. This situation showed that there were also bound proteins in the column, which were eluted with the elution buffer.

A total of 26 fractions were collected during purification, and all were analysed in terms of peptidase activity. As seen in Fig. 1b, the fractions which had high absorbance values (UV plot) also showed peptidase activity. Activity results showed that a considerable amount of the peptidase could not bind to the column and passed through the column directly. Furthermore, the peptidase molecules which had stayed in the column left it as soon as the washing stage started. Moreover, the peptidase activity of the elution fractions showed that a small amount of the enzyme could bind to the column.

SDS-PAGE results are shown in Fig. 2. All of the fractions collected were loaded onto the gels (the fractions for which a protein band could not be observed are not shown in the figure). According to Fig. 2, there are protein bands at the level of approximately $36 \mathrm{kDa}$ from the beginning of the CES to the eighth fraction. While the intensity of the bands is clear for the second to sixth fractions, a decrease in band intensity was observed for the seventh and eighth fractions. Furthermore, the band intensity of the fractions was also well correlated with their peptidase activity. Therefore, it was thought that these $36 \mathrm{kDa}$ bands most probably belonged to peptidase. On the other hand, the presence of protein bands other than at $36 \mathrm{kDa}$ indicates partial purification.

A $36 \mathrm{kDa}$ protein band could not be observed for the fractions collected during elution (16-18) which implies that this protein could not bind to the column. However, there were protein bands at the level of $100 \mathrm{kDa}$. Therefore, it can be said that the enzyme solution contained different types of peptidase. In order to make a comparison, elution fractions 16-18 were loaded onto the SDS-PAGE gels again without desalting (Fig. 2 gel b) and $36 \mathrm{kDa}$ protein bands were observed with this method. The reason why bands could not be observed in the gel was probably due to the 3.6-fold dilution that occurred during desalting. 

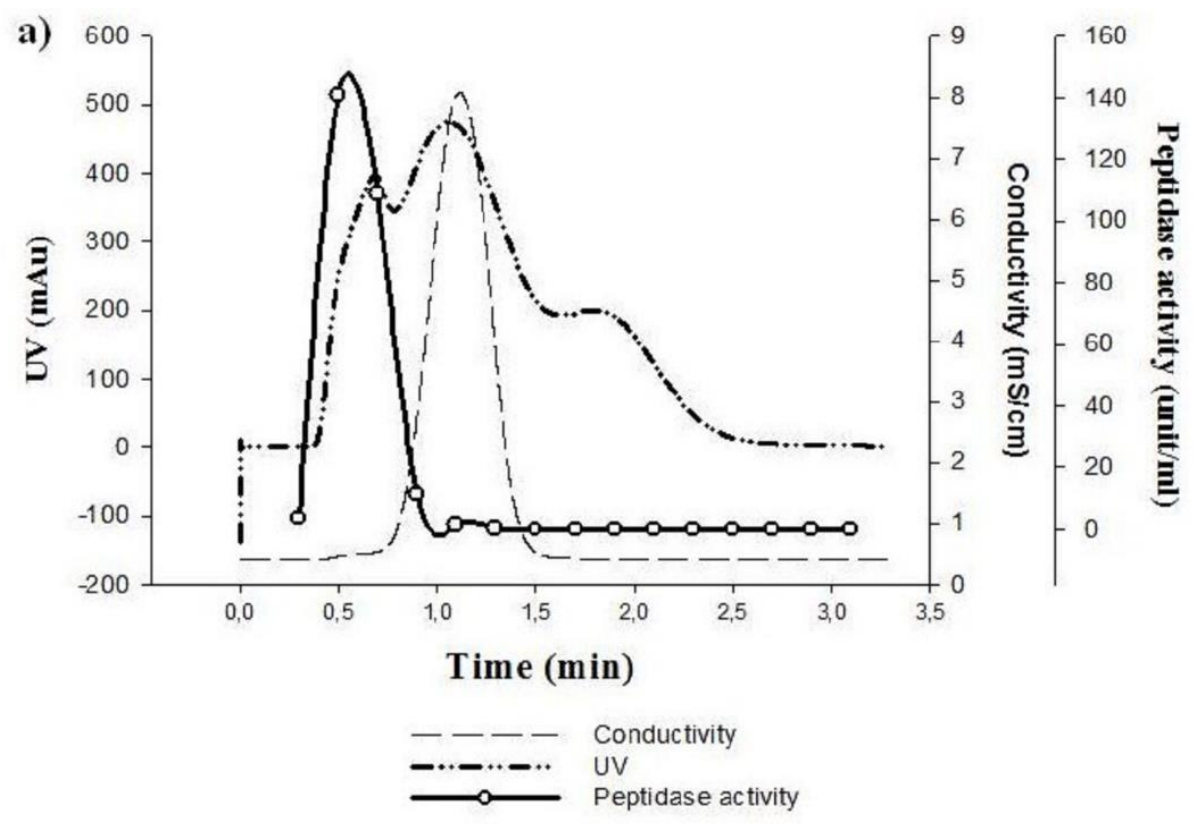

b)

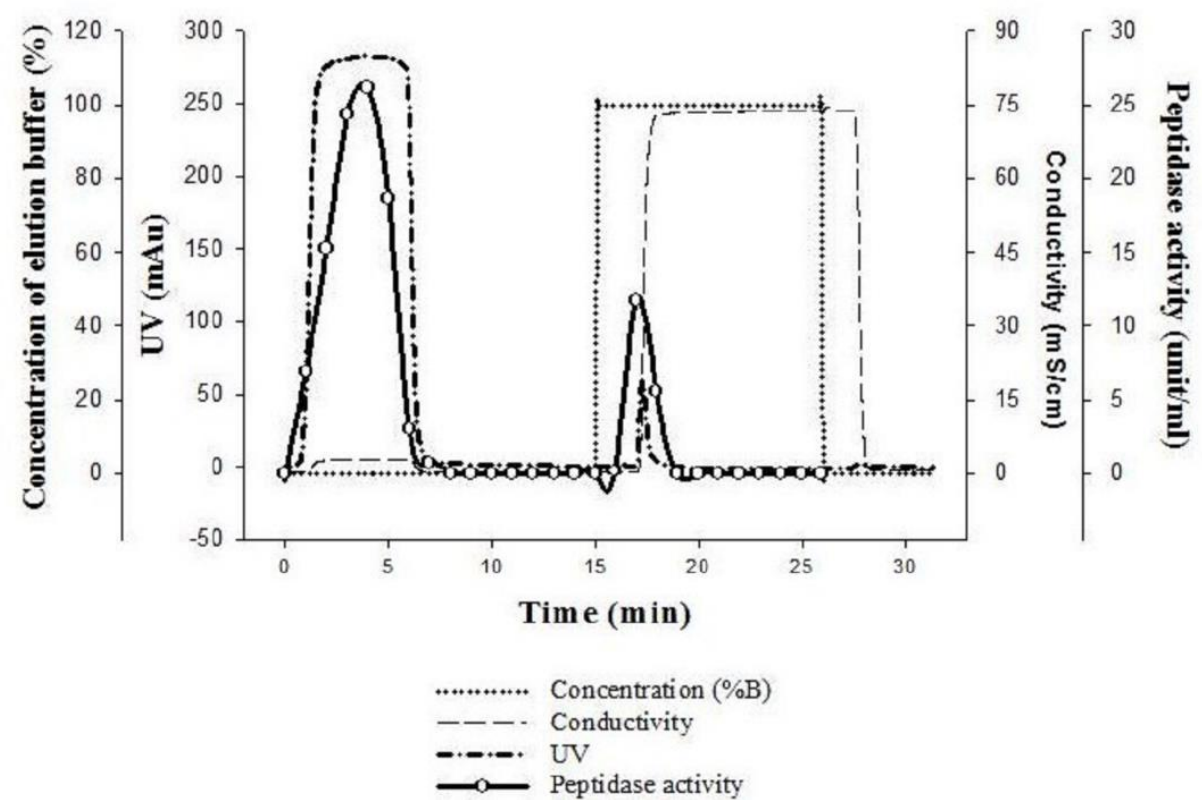

Fig. 1. Changes in conductivity, UV (absorbance), and peptidase activity values during the passage of concentrated crude enzyme solution through a) HiTrap desalting column and b) HiTrap Blue HP column.

A zymogram gel image is also shown in Fig. 2. It was observed that there were no bands at the level of both 36 $\mathrm{kDa}$ and $100 \mathrm{kDa}$ for the elution fractions. Moreover, the right part of the gel was almost entirely dark indicating that the casein in the gel did not degrade. In other words, there was no observable hydrolysis in the gel related to the proteolytic activity for elution fractions 17 and 18, although it is known that these fractions had peptidase activity according to the spectrophotometric analysis.

The clear bands at the level of $36 \mathrm{kDa}$ in Fig. 2 indicate peptidase activity, and the band intensities are also in good correlation with the activity results given as $\mathrm{U} / \mathrm{mL}$ (Fig. 1b). There are also clear bands at the level of $15 \mathrm{kDa}$, and this situation points out that the CES may also contain different types of peptidase.

A remarkable subject related to the gel images (Fig. 2) was the concentrated enzyme solution, which did not show a protein band at the molecular weight level of $36 \mathrm{kDa}$ in the SDS-PAGE gel but did show a clear band in the zymogram at the same level as an indicator of peptidase activity. The probable reason for this situation was thought to be the heating treatment, which was the only difference in the processes applied for SDS-PAGE and zymography samples. Owing to the high protein concentration, the conformational structure of the protein in the concentrated enzyme solution could change or be damaged. 


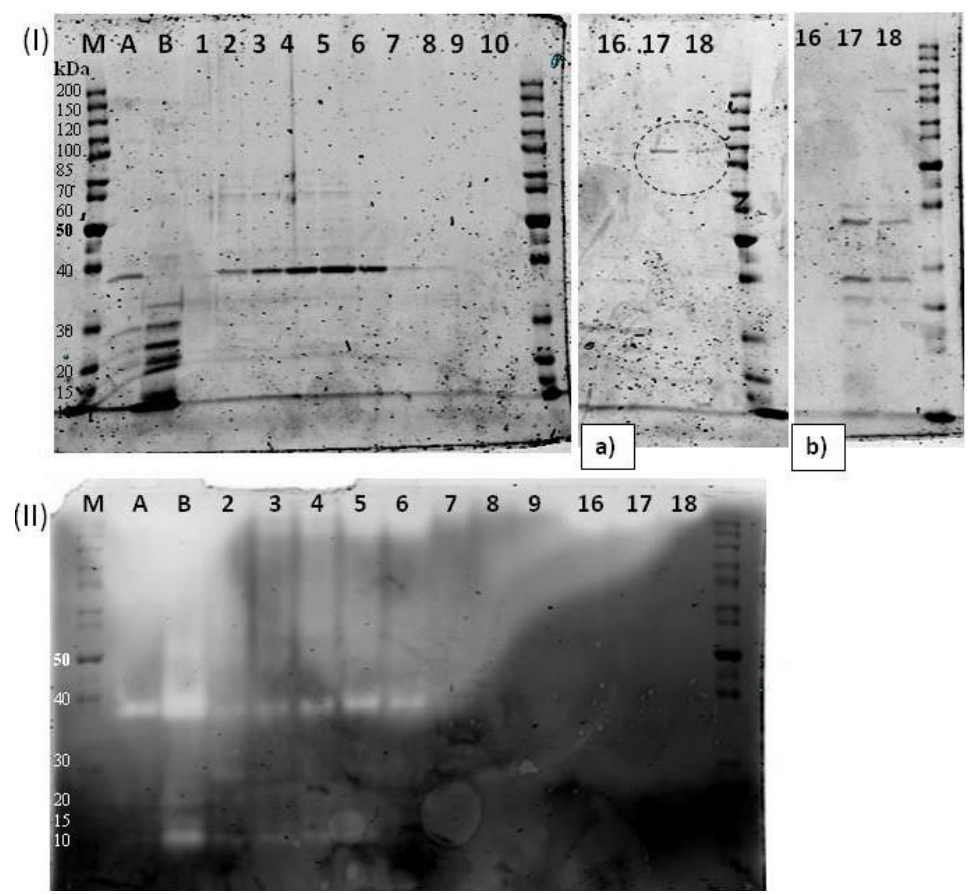

Fig. 2. (I): SDS-PAGE and (II): zymogram image of fractions collected during purification. (M: marker; A: crude enzyme solution; B: concentrated enzyme solution; 1-18: fraction numbers; a) desalting applied; b) fractions without desalting.

Table 1. Peptidase activity levels of the combined fractions after purification with a HiTrap Blue column and the activity remaining (\%) after mixing peptidase inhibitors.

\begin{tabular}{|c|c|c|c|c|c|c|c|}
\hline & & & & & Inl & ibitor $^{1}$ & \\
\hline Fra & & Peptidase activity & Specific activity & PEP-A & E-64 & O-FEN & PMSF \\
\hline & & $46.96 \pm 0.66$ & 582.56 & $86.40 \pm 0.56$ & $73.19 \pm 0.28$ & $13.02 \pm 1.17$ & $63.60 \pm 0.08$ \\
\hline & & $248.08 \pm 15.32$ & 1717.30 & $84.72 \pm 0.40$ & $90.03 \pm 0.32$ & $22.88 \pm 0.65$ & $30.42 \pm 0.17$ \\
\hline & & $60.79 \pm 0.16$ & 682.43 & $100.64 \pm 2.20$ & $92.23 \pm 1.68$ & $12.90 \pm 0.00$ & $71.43 \pm 0.97$ \\
\hline Sample & $1-2$ & 0 & . & - & - & - & - \\
\hline loading & $3-4-5$ & $23.77 \pm 0.57$ & 488.10 & $98.36 \pm 0.41$ & $101.17 \pm 0.74$ & $0.25 \pm 0.00$ & $89.19 \pm 0.50$ \\
\hline Washing & $6-7-8$ & $25.38 \pm 0.92$ & 649.43 & $102.68 \pm 0.00$ & $91.35 \pm 1.16$ & $0.78 \pm 0.00$ & $91.30 \pm 0.46$ \\
\hline step & $9-15$ & $1.74 \pm 0.02$ & $*$ & $94.40 \pm 0.0$ & $96.00 \pm 4.52$ & 0.00 & $58.46 \pm 1.13$ \\
\hline Elution & 16 & 0 & - & - & - & - & - \\
\hline step & $17-18$ & $19.08 \pm 0.06$ & * & $94.17 \pm 0.82$ & $88.35 \pm 1.92$ & $25.85 \pm 0.27$ & $47.59 \pm 0.82$ \\
\hline
\end{tabular}

${ }^{1}$ The inhibitor concentrations are the final concentrations reached after mixing the enzyme and the inhibitors; activity was measured after the enzyme solution and inhibitors were mixed and kept for $30 \mathrm{~min}$ at room temperature. Calculations were made by accepting the activity of the samples without inhibitor as $100 \%$.

A: crude enzyme solution; B: concentrated enzyme solution (with ultrafiltration); C: combined fractions (1-6) during buffer exchange process (HiTrap desalting column); sample loading, washing step, and elution step are for HiTrap Blue HP column.

*Protein content could not be determined due to the very low concentration; consequently, specific activity could not be calculated.

Table 2. Peptidase purification profile.

\begin{tabular}{cccccccc}
\hline \hline & $\begin{array}{c}\text { Volume } \\
(\mathbf{m L})\end{array}$ & $\begin{array}{c}\text { Peptidase } \\
\text { activity }(\mathbf{U} / \mathbf{m L})\end{array}$ & $\begin{array}{c}\text { Protein } \\
(\mathbf{m g} / \mathbf{m L})\end{array}$ & $\begin{array}{c}\text { Specific } \\
\text { activity } \\
(\mathbf{u n i t} / \mathbf{m g})\end{array}$ & $\begin{array}{c}\text { Total } \\
\text { activity } \\
(\text { Unit })\end{array}$ & $\begin{array}{c}\text { Efficiency } \\
(\boldsymbol{\%})\end{array}$ & $\begin{array}{c}\text { Purification } \\
\text { coefficient }\end{array}$ \\
\hline \hline A & 50.00 & $40.13 \pm 2.86$ & $0.15 \pm 0.00$ & 265.10 & 2006.57 & 100.00 & 1.00 \\
B & 5.00 & $251.25 \pm 0.80$ & $0.99 \pm 0.01$ & 253.35 & 1256.23 & 62.61 & 0.96 \\
C & 21.33 & $49.06 \pm 0.45$ & $0.13 \pm 0.02$ & 365.90 & 1046.59 & 52.16 & 1.38 \\
D & 25.06 & $20.26 \pm 0.00$ & $0.05 \pm 0.00$ & 405.14 & 518.58 & 25.84 & 1.53 \\
\hline \hline
\end{tabular}

A: crude enzyme solution; B: concentrated enzyme solution (with ultrafiltration); C: combined fractions during buffer exchange (1-6); D: combined fractions during affinity chromatography (3-8).

Specific activity, total activity, efficiency, and purification coefficient were calculated by using mean values of peptidase activity and protein content. 

fractions, some of the fractions were combined, and the peptidase and specific activity of these combined fractions were determined (Table 1). According to Table 1, fractions 3-8 were the best in terms of peptidase activity. However, the higher level of specific activity for fractions 6-8 indicates better purification of these fractions. Peptidase activity was also high for elution fractions 17 and 18, but their specific activity could not be calculated since the protein content was quite low.

As previously expressed, the crude enzyme solution is thought to contain different types of peptidase. In order to determine this, combined fractions were mixed with peptidase inhibitors and analysed for peptidase activity again. Activity levels were calculated relatively and are shown as remaining activity in Table 1 . The substantial FEN showed that the major peptidase in all of the fractions was a metallopeptidase. In the literature, the molecular weights of metallopeptidases produced by Bacillus species are 19 (Sabirova et al. 2010), 23.5 (Choi et al. 2017), 30 (Matta \& Punj 1998), 36 (Manni et al. 2008), 37.6 (See et al. 2018), 38 (Lauer et al. 2000), 40.08 (Tian et al. 2019), 45 (Sousa et al. 2007), 60 (Lee et al. 2016), 134 (Lee et al. 2002), 210 and 215 kDa (D'Costa et al. 2013). In this study, because the major peptidase was determined as a metallopeptidase, the clear band at the molecular level of $36 \mathrm{kDa}$ in the zymogram probably belonged to a metallopeptidase. Furthermore, the observation of a decrease in activity in the presence of PMSF refers to the presence of serine peptidases in the crude enzyme solution (especially in the elution fractions).

As shown in Table 1, the peptidase activity of fractions $3-5$, 6-8, and 9-15 was almost completely lost in the presence of O-FEN. Because these fractions were metallopeptidase-rich, it was decided to use a combination of them in the characterization studies except the fractions 9-15, which have very low peptidase activity $(1.7 \mathrm{U} / \mathrm{mL})$ and could have caused dilution. Therefore, only fractions 3-8 were used in the characterization studies.

Although there were elution fractions that showed peptidase activity, they were not used in the
Depending on the peptidase activity level of the decrease observed in activity level in the presence of $\mathrm{O}$ -

characterization studies since no band could be determined for them in the zymogram. Moreover, the specific activity could not be calculated and, consequently, it was not possible to determine the purity level. The peptidase purification profile (from crude enzyme to fractions 3-8) is shown in Table 2. It can be seen that only partial purification could be obtained, with a purification coefficient of 1.53 and efficiency of 25.84 $\%$. Sousa et al. (2007) purified B. cereus metallopeptidase with a three-step chromatographic procedure and determined a purification coefficient and efficiency as 57.6 and $2.16 \%$, respectively. They obtained good purification despite the low-efficiency level. Manni et al. (2008) also used three-step chromatographic purification after an ultrafiltration step for the metallopeptidase of $B$. cereus SV1 and obtained a similar efficiency level (27.74 $\%$ ) as in our study. However, the purification coefficient was determined as 6.09. In another study, Bacillus subtilis FBL-1 peptidase was purified 94.89-fold with a yield of $2.3 \%$ (Si et al. 2018).

\section{Peptidase characterization}

Characterization studies were applied both for CES and the combined fractions 3-8 (partially purified peptidase; PPPase) to obtain a comparison.

\section{Optimum $\mathrm{pH}$ of peptidase and $\mathrm{pH}$ stability}

The peptidase activity results for CES and PPPase at different $\mathrm{pH}$ values (6.0-13.0) are shown in Fig. 3. It is obvious from the results that despite the activity loss in PPPase, the activity profiles of both CES and PPPase, exhibited at different $\mathrm{pH}$ values, are quite similar. The optimum peptidase activity was obtained at $\mathrm{pH} 7.5$ for both CES $(50.28 \mathrm{U} / \mathrm{mL})$ and PPPase $(25.57 \mathrm{U} / \mathrm{mL})$. The activity decreased at lower and higher $\mathrm{pH}$ levels. Generally, the optimum activity for metallopeptidases is in the $\mathrm{pH}$ range between 7.0 and 8.0 (Rao et al. 1998, Salleh et al. 2006). Furthermore, Salleh et al. (2006) declared that metallopeptidases are the most unstable type of peptidase and can undergo autolysis quickly in the $\mathrm{pH}$ ranges below 6.0 and above 9.0. Si et al. (2018) obtained the highest activity at $\mathrm{pH} 9.0$ for $B$. subtilis FBL-1 metallopeptidase and observed a sharp decrease in the enzyme activity above this value.

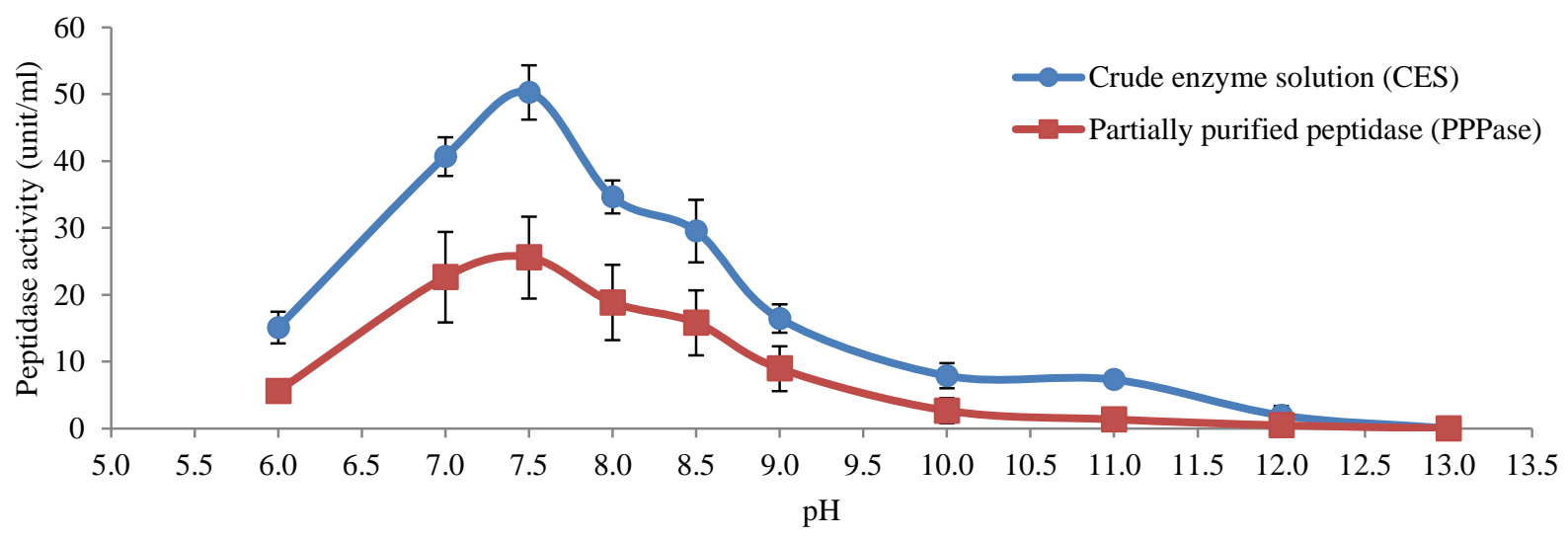

Fig. 3. Peptidase activity results at different $\mathrm{pH}$ levels. 
On the other hand, Sharmila et al. (2018) determined pH 8.0 as the optimum $\mathrm{pH}$ level for a calcium-dependent peptidase from $B$. subtilis CFR5. The optimum $\mathrm{pH}$ value for B. cereus metallopeptidase was determined as 7.0 and 8.0 by Sousa et al. (2007) and Manni et al. (2008), respectively. Matta \& Punj (1998) determined the optimum pH level for B. polymyxa B-17 as 7.5. The major peptidase in enzyme solutions obtained in our study was a metallopeptidase. Therefore, the results are in accordance with the literature data. Additionally, while CES retained $80.9 \%$ and $68.9 \%$ of its initial peptidase activity at $\mathrm{pH} 7.0$ and 8.0, respectively, the closest $\mathrm{pH}$ levels to the optimum $\mathrm{pH}$, PPPase retained $88.6 \%$ and $73.7 \%$ of its initial peptidase activity in the same conditions.

The stability of the produced peptidase solutions at different $\mathrm{pH}$ levels are given as remaining activity (\%) in Fig. 4. According to the results, the peptidase retained a considerable amount of its initial activity in the $\mathrm{pH}$ range 7.0-9.0 after incubation at $37^{\circ} \mathrm{C}$ for $2 \mathrm{~h}$ (Fig. 4a). However, a substantial decrease in peptidase activity was observed especially at $\mathrm{pH}$ values higher than 9.0. In the case of a longer incubation period (18 h), CES showed stability by retaining approximately $75-80 \%$ of its initial activity in the $\mathrm{pH}$ range 7.0-8.0; on the other hand, PPPase could only retain $27 \%$ and $63 \%$ of its activity at $\mathrm{pH} 7.0$ and 8.0, respectively. Although the optimum $\mathrm{pH}$ level was 7.5 for PPPase, it retained its activity for a longer period of time at $\mathrm{pH}$ 8.0. This situation could be attributed to the possible presence of another type of peptidases, most probably serine peptidases, which might be in the enzyme solutions. As shown in Table 1, the presence of PMSF, which is the inhibitor of serine peptidases, caused a decrease in the peptidase activity. It was determined that serine peptidases are generally stable at $\mathrm{pH} 8.0$ (Mothe \& Sultanpuram 2016, Hammami et al. 2020). It was observed that the stability of the enzyme decreased in alkaline conditions, especially for more extended incubation periods (Fig. 4b). However, the stability of CES was better than that of PPPase, probably because it contains different types of peptidase, which may have higher optimum pH levels. Choi et al. (2017) observed that the purified serine metallopeptidase was stable in a $\mathrm{pH}$ range of $5.5-8.0$ at $36^{\circ} \mathrm{C}$ for $2 \mathrm{~h}$.

a)

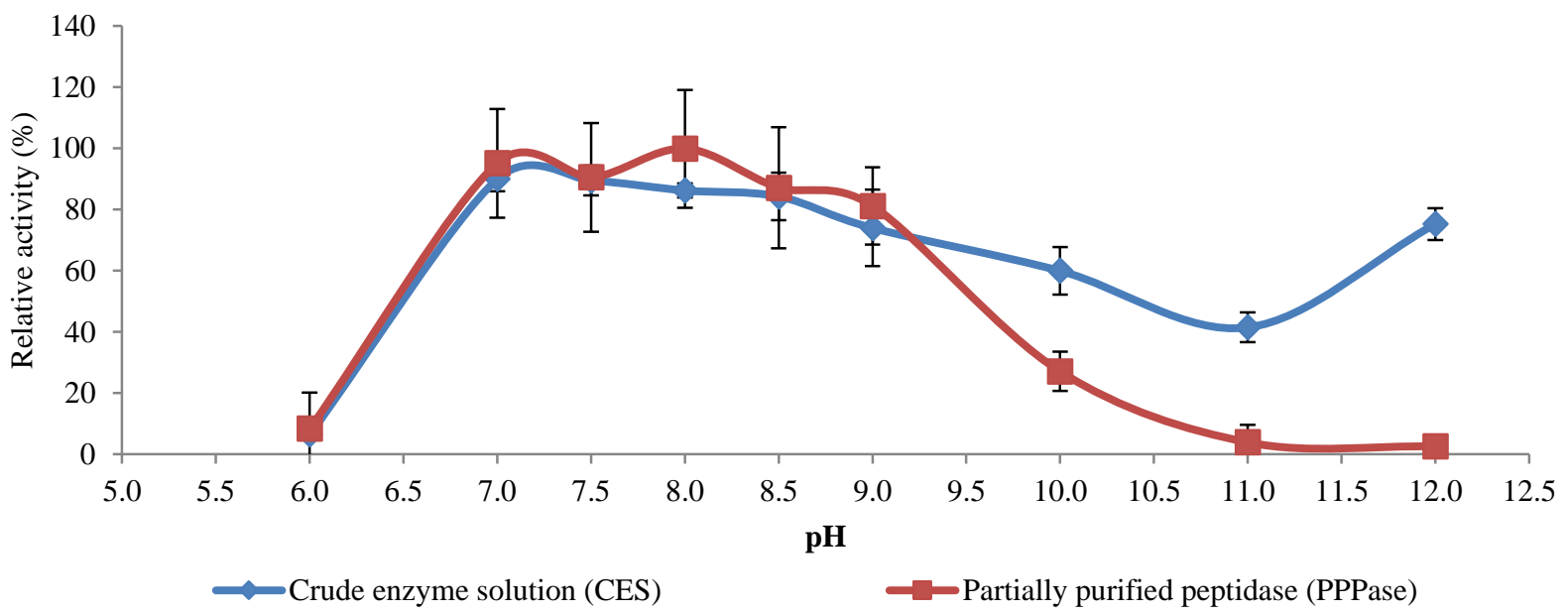

b)

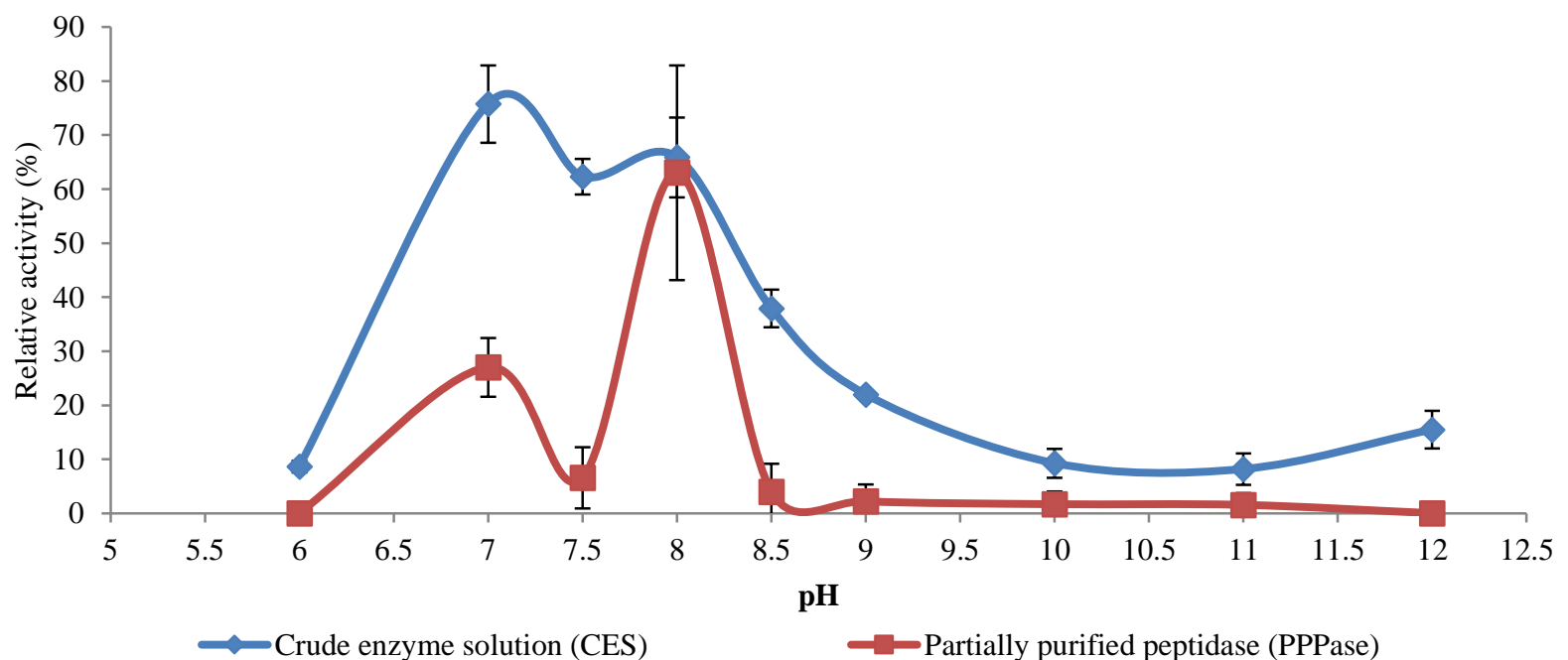

Fig. 4. pH stability of peptidase after a) $2 \mathrm{~h}$ and b) $18 \mathrm{~h}$ of incubation. 


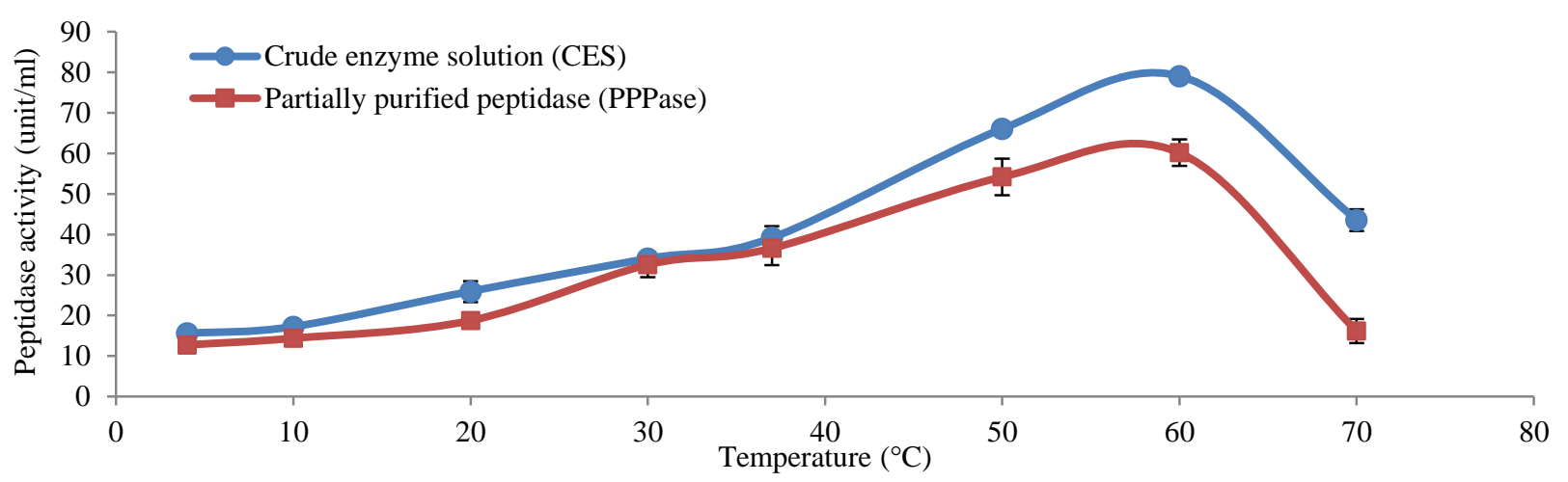

Fig. 5. Peptidase activity results at different temperatures.
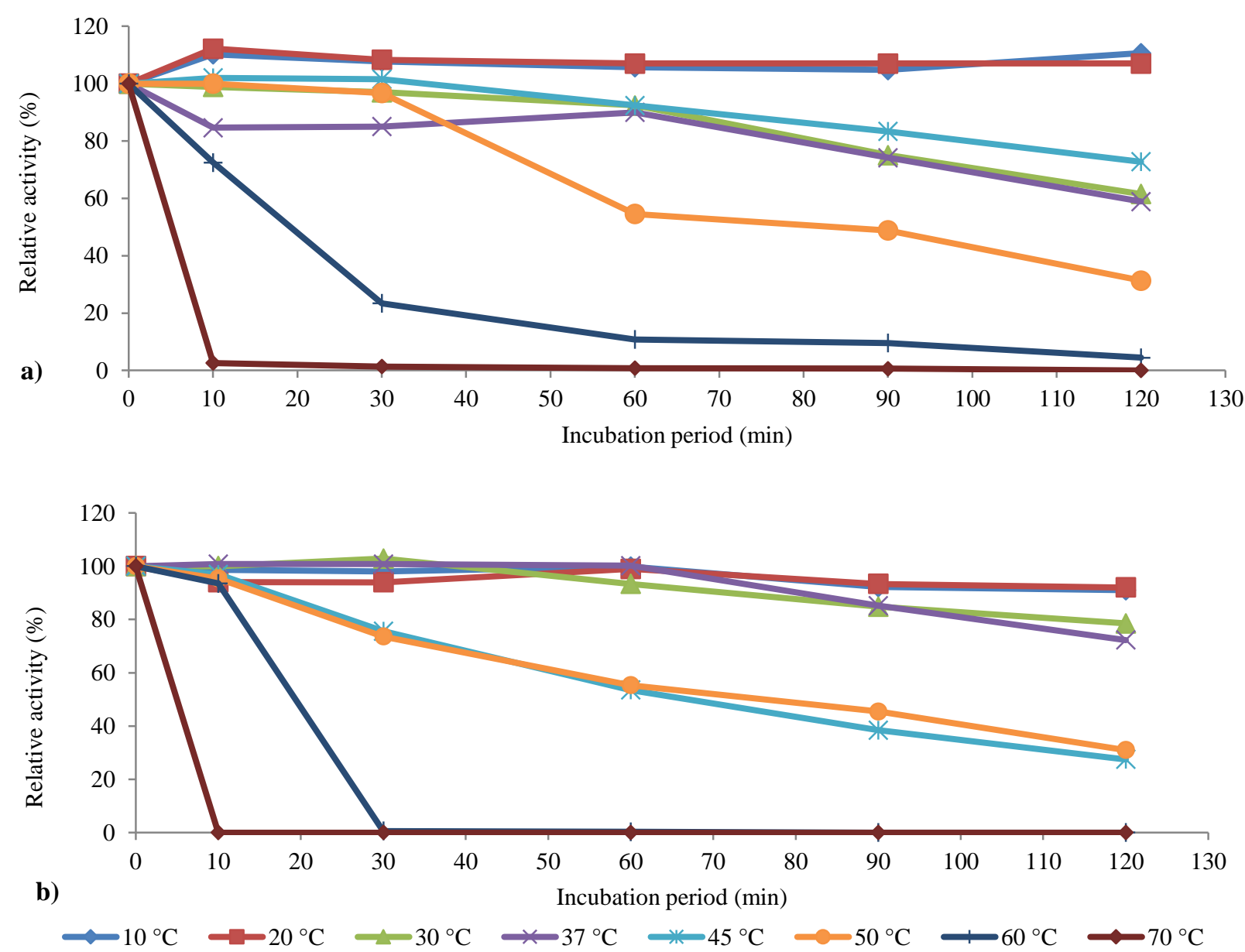

Fig. 6. Stability of a) CES and b) PPPase at different temperatures.

Manni et al. (2008) determined that metallopeptidase retained its initial activity almost entirely in the $\mathrm{pH}$ range 7.5-9.0 at $30^{\circ} \mathrm{C}$ for $15 \mathrm{~min}$. According to a previous study (Ghorbel et al. 2003), a crude peptidase solution containing metallopeptidase retained more than $95 \%$ of its initial activity after incubation at $50^{\circ} \mathrm{C}$ for 1 and $3 \mathrm{~h}$ at $\mathrm{pH}$ 8.0. In our study, CES showed 75-80\% stability after $18 \mathrm{~h}$ of incubation, which can be evaluated as having good $\mathrm{pH}$ stability.
A surprising result was obtained at $\mathrm{pH}$ 12.0. While PPPase was inactivated at this $\mathrm{pH}$ level, CES retained approximately $75.26 \%$ of its activity after $2 \mathrm{~h}$ of incubation despite having a much lower activity level of 1.9 $\mathrm{U} / \mathrm{mL}$. This was probably due to the serine peptidase presence in CES. As declared earlier (Table 1), the CES peptidase activity remaining in the presence of PMSF was approximately $64 \%$, which is evidence of serine peptidases. These types of peptidase are generally 
alkaline. If the optimum $\mathrm{pH}$ for these serine peptidases is close to $\mathrm{pH} 12$, it is probable for CES to retain its activity at this $\mathrm{pH}$ level.

\section{Optimum temperature of peptidase and temperature $\underline{\text { stability }}$}

Peptidase activity results for CES and PPPase at different temperatures $\left(4-70^{\circ} \mathrm{C}\right)$ are shown in Fig. 5. The optimum temperature of the peptidase solutions was determined as approximately $58-60^{\circ} \mathrm{C}$ and an apparent decrease in activity was observed after this temperature. The optimum temperature of $B$. cereus metallopeptidase was determined as 37,45 , and $55^{\circ} \mathrm{C}$ by D'Costa et al. (2013), Sousa et al. (2007), and Manni et al. (2008), respectively. Lee et al. (2002) determined the optimum temperature of a keratinolytic metallopeptidase produced by Bacillus sp. SCB- 3 as $40^{\circ} \mathrm{C}$; on the other hand, metallopeptidases produced by $B$. mojavensis Roberts et al. (Amal \& Abdelouahab 2017), $B$. licheniformis Weigmann (Mardina \& Yusof 2016), B. subtilis (Ehrenberg) Cohn (Lauer et al. 2000, Rehman et al. 2017) and B. polymyxa B-17 Prazmowski (Sabirova et al. 2010) showed optimum activity at 70, 65, 55 and $50^{\circ} \mathrm{C}$, respectively. Bacillus spp. G51 and Bacillus sp. APCMST-CS4 peptidases were determined to show optimum proteolytic activity at $60^{\circ} \mathrm{C}$ (Iglesias et al. 2017, Maruthiah et al. 2017). Cold-active metallopeptidase, which shows optimum enzyme activity at $20^{\circ} \mathrm{C}$, was also purified from Bacillus sp. (Furhan et al. 2019). It is evident from the results of different studies that metallopeptidases produced by different strains of the same species can have different optimum temperatures.

The initial peptidase activity of CES and PPPase prior to the incubation applied for the stability tests was measured as 37.05 and $33.64 \mathrm{U} / \mathrm{mL}$, respectively (Fig. 6). Results indicated that CES exhibited overall a higher stability profile compared with PPPase, which may imply that some of the impurities that were present in the crude supernatant had a stabilizing effect on the enzymes. Both enzyme fractions were inactivated immediately at $70^{\circ} \mathrm{C}$, and at $60^{\circ} \mathrm{C}$, which was the optimum temperature for peptidolytic activity of $B$. amyloliquefaciens $\mathrm{FE}-\mathrm{K} 1,93.5$ $\%$ of PPPase activity was maintained for the first 10 minutes and lost quickly after that. It may be advisable to apply a milder temperature than the optimum in using either fraction and carry out digestion at $50^{\circ} \mathrm{C}$ where the enzyme half-life would be approximately one hour. The results obtained are comparable to those of Manni et al. (2008) who also reported that $60 \%$ of metallopeptidase activity remained after incubation at $50^{\circ} \mathrm{C}$ for $1 \mathrm{~h}$, and of Sousa et al. (2007) who found $55 \%$ activity remaining at the same temperature after $2 \mathrm{~h}$ of incubation. Maruthiah et al. (2017) reported that a more than $80 \%$ activity of their serine metallopeptidase remained after $1.3 \mathrm{~h}$ of incubation within the temperature range between 40 and $60^{\circ} \mathrm{C}$. Furhan et al. (2019) observed that more than half of the activity of cold-active metallopeptidase was retained between $20-30^{\circ} \mathrm{C}$.

\section{Effect of peptidase inhibitors on enzyme activity}

The effect of peptidase inhibitors was investigated in the purification step for different fractions (Table 1). In this section, the effect of different concentrations of the inhibitors on enzyme activity was tested. The results are given in Table 3 as relative activity (\%) according to the activity of inhibitor-free enzyme solutions. The activity of inhibitor-free CES and PPPase was $81.23 \mathrm{U} / \mathrm{mL}$ and $40.76 \mathrm{U} / \mathrm{mL}$, respectively. Activity analysis was tested at optimum $\mathrm{pH}$ (7.5) and temperature $\left(60^{\circ} \mathrm{C}\right)$. A large decrease in peptidase activities of CES and inactivation of PPPase were observed in the presence of O-FEN and EDTA, which are inhibitors of metallopeptidases. The Pearson correlation test results were given in Table 4 . The decrease in activity was correlated with the concentration of O-FEN: a higher concentration of OFEN resulted in a higher decrease in peptidase activity $(\mathrm{p}<$ 0.05). It was considered that an O-FEN concentration higher than $4 \mathrm{mM}$ might completely inactivate the enzyme. It was determined that even the lowest concentration of EDTA completely inactivated PPPase, but the decrease in CES activity did not depend on EDTA concentration. Probably, in the presence of EDTA, even at the lowest concentration, all of the metallopeptidases were inactivated, and the remaining activity of $12 \%$ could be due to another types of peptidases.

The enzyme solutions in our study are comprised mostly of metallopeptidases; however, they also contain other types of peptidases since there is a decrease in activity in the presence of peptidase inhibitors other than O-FEN and EDTA. The variation in the activity of other peptidases was not correlated to the increase in inhibitor concentrations, probably due to the low amount of other peptidases. A significant positive correlation was observed between PMSF concentration and peptidase activity of CES, but it may be due to the complex structure of the CES (Table 4).

Rehman et al. (2017) and Si et al. (2018) reported their enzyme as metallopeptidase after observing a considerable amount of decrease in the activity in the presence of EDTA. Manni et al. (2008) declared their peptidase as a metallopeptidase due to its complete inactivation at $20 \mathrm{mM}$ of EDTA. Furthermore, they related the decrease in peptidase activity with increasing PMSF concentration to the presence of a serine group close to the active site of the enzyme. Sabirova et al. (2010) determined the remaining enzyme activity as 3.9 $\%$ and $0.1 \%$ in the presence of $10 \mathrm{mM}$ of EDTA and 10 $\mathrm{mM}$ of O-FEN, respectively.

Effect of some organic solvents and surfactants on peptidase activity

Enzymes are generally inactivated or denatured in the presence of organic solvents. However, being resistant to organic solvents makes the use of an enzyme in synthesis reactions possible. Peptidases are among the most valuable catalysts used in food, pharmaceutical, and detergent industries because they hydrolyse peptide bonds in aqueous environments and synthesize peptide bonds in microaqueous environments (Gupta 1992, Rahman et al. 2007). Additionally, peptidases used in detergent industry must be resistant to detergent supplements (Kumar \& Takagi 1999). 
Table 3. Effect of peptidase inhibitors on enzyme activity at different concentrations (relative activity, \%).

\begin{tabular}{|c|c|c|c|}
\hline 总 & 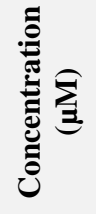 & 穵 & 总 \\
\hline \multirow{3}{*}{ PEP-A } & 5 & $91.28 \pm 6.17$ & $88.92 \pm 1.84$ \\
\hline & 10 & $88.33 \pm 4.47$ & $81.53 \pm 1.84$ \\
\hline & 20 & $89.97 \pm 0.00$ & $85.01 \pm 0.61$ \\
\hline \multirow{3}{*}{ E-64 } & 10 & $90.41 \pm 0.31$ & $88.48 \pm 1.23$ \\
\hline & 20 & $89.10 \pm 5.55$ & $75.45 \pm 1.23$ \\
\hline & 40 & $95.42 \pm 1.85$ & $77.62 \pm 0.00$ \\
\hline \multirow{3}{*}{ PMSF } & 1 & $76.01 \pm 1.54$ & $88.27 \pm 0.31$ \\
\hline & 2 & $79.39 \pm 0.46$ & $74.58 \pm 0.00$ \\
\hline & 4 & $86.15 \pm 2.62$ & $87.40 \pm 0.31$ \\
\hline \multirow{3}{*}{ O-FEN } & 1 & $38.21 \pm 0.16$ & $33.38 \pm 0.41$ \\
\hline & 2 & $26.51 \pm 0.51$ & $8.12 \pm 0.28$ \\
\hline & 4 & $17.16 \pm 0.09$ & $1.93 \pm 0.09$ \\
\hline \multirow{3}{*}{ EDTA } & 1 & $12.04 \pm 0.39$ & $0.00 \pm 0.00$ \\
\hline & 2 & $12.22 \pm 0.14$ & $0.00 \pm 0.00$ \\
\hline & 4 & $13.41 \pm 0.16$ & $0.00 \pm 0.00$ \\
\hline
\end{tabular}

PEP-A: Pepstatin A; E-64: Epoxysuccinyl-L-leucylamido-(4guanidino) butane; PMSF: Phenylmethylsulphonyl fluoride; OFEN: 1,10-phenanthroline; EDTA: Ethylenediaminetetraacetic acid

The peptidase activity was measured at optimum temperature $\left(60^{\circ} \mathrm{C}\right)$ and $\mathrm{pH}(7.5)$ after the enzyme solution and inhibitors were mixed and kept at $37^{\circ} \mathrm{C}$ for $30 \mathrm{~min}$.

Table 4. Correlation results between inhibitor concentration and relative peptidase activity.

\begin{tabular}{ccc}
\hline \hline Inhibitor & CES & PPPase \\
\hline \hline \multirow{2}{*}{ PEP-A } & $\mathrm{r}=-0.096$ & $\mathrm{r}=-0.338$ \\
& $\mathrm{p}$-value $=0.856$ & $\mathrm{p}$-value $=0.513$ \\
E-64 & $\mathrm{r}=0.648$ & $\mathrm{r}=-0.640$ \\
& $\mathrm{p}$-value $=0.164$ & $\mathrm{p}$-value $=0.171$ \\
PMSF & $\mathrm{r}=0.958$ & $\mathrm{r}=0.133$ \\
& $\mathrm{p}$-value $=0.003$ & $\mathrm{p}$-value $=0.802$ \\
O-FEN & $\mathrm{r}=-0.968$ & $\mathrm{r}=-0.864$ \\
& $\mathrm{p}$-value $=0.002$ & $\mathrm{p}$-value $=0.026$ \\
EDTA & $\mathrm{r}=0.936$ & $*$ \\
& $\mathrm{p}$-value $=0.006$ & \\
\hline \hline
\end{tabular}

r: The Pearson correlation coefficient

r value closed to " 1 " or "-1" represents a positive or negative relationship, respectively.

The p-value of less than 0.05 indicates that the correlation is statistically significant.

*Peptidase activity was zero for all EDTA concentrations.

The effects of some organic solvents and surfactants on CES and PPPase are given in Table 5. It was observed that enzyme solutions were resistant to the applied organic solvents, and there was no substantial loss in enzyme activity. Furthermore, all of the applied organic solvents resulted in an increase in the enzyme activity of CES. Xylene and ethanol at higher concentrations, and acetone and acetonitrile at lower concentrations were more effective for increasing the peptidase activity. An increase in PPPase activity was only obtained in the presence of xylene and acetonitrile.
A $14 \%$ increase in PPPase activity was obtained in the presence of $1 \%$ acetonitrile (Table 5). Sousa et al. (2007) determined the increase as $3 \%$ under the same conditions as in our study. A decrease in activity was observed in the presence of ethanol and acetone. It is noteworthy that more than $85 \%$ of the activity was retained after incubation at $37^{\circ} \mathrm{C}$ for $30 \mathrm{~min}$. However, B. cereus metallopeptidase retained $80 \%$ of its initial activity after incubation at $60^{\circ} \mathrm{C}$ for $4 \mathrm{~h}$ in the presence of benzene, toluene, acetone, xylene and isopropanol (Doddapaneni et al. 2009). Wang et al. (2006) determined that the peptidase activity of Bacillus sp. TKU004 CES remaining after incubation at 4 and $25^{\circ} \mathrm{C}$ for 10 days was $65 \%$. In another study, it was shown that the activity decreased by $21 \%$ and increased by $31 \%$ with acetone and ethanol, respectively (Maruthiah et al. 2017). Bacillus sp. metallopeptidase was found stable in the presence of several organic solvents $(40 \%, \mathrm{v} / \mathrm{v})$ after $1 \mathrm{~h}$ at $40^{\circ} \mathrm{C}$ (Qureshi et al. 2018).

Although the resistance of CES to detergent supplements was higher than that of PPPase, the results showed that neither enzyme solutions showed resistance to SDS. The peptidase activity of CES decreased to a level of $5 \%$ depending on the concentration in the presence of SDS. Complete inactivation, on the other hand, was observed for PPPase. Approximately $80 \%$ of the peptidase activity was retained in the presence of Triton $\mathrm{X}-100$. It was observed that the activity increased by $8 \%$ in the presence of $0.1 \%$ Triton X-100; however, the activity decreased with increasing concentration. Sousa et al. (2007) determined similarly that B. cereus metallopeptidase was inactivated by SDS and retained most of its activity in the presence of Triton X-100. In contrast, B. cereus SV1 metallopeptidase retained $90 \%$ and $35 \%$ of its activity in the presence of $0.1 \%$ and 1.0 $\%$ SDS, respectively (Manni et al. 2010). Rehman et al. (2017) determined an increase in peptidase activity in the presence of SDS, but a decrease with Triton X-100. Mardina \& Yusof (2016) observed that B. licheniformis metallopeptidase was stable with $1 \%$ Triton $\mathrm{X}-100$, but the activity of the enzyme was increased by $82.7 \%$ in the presence of SDS. Iglesias et al. (2017) determined a 2.9 $\%$ increase and an approximately $20 \%$ decrease in the activity of Bacillus sp. G51 metallopeptidase in the presence of $1 \%$ and $5 \%$ Triton X-100, respectively.

A positive effect of Tween 20 and Tween 80 on peptidase activity was also observed (Table 5). The activity of CES was increased by $25 \%$ and $29 \%$ in the presence of $1 \%$ Tween 20 and Tween 80 , respectively. Tween $20(0.1 \%)$ caused a decrease in PPPase activity; however, stabilization was obtained at higher concentrations of Tween 20. Tian et al. (2019) observed a $14 \%$ and $31 \%$ increase in the enzyme activity with $1 \%$ Tween 20 and Tween 80, respectively.

\section{Effect of metal ions on enzyme activity}

The effect of metal ions on peptidase activity is shown in Table 6 . The activities of metal ion-free and 1:1 diluted CES and PPPase were 34.09 U/mL and 20.00 $\mathrm{U} / \mathrm{mL}$, respectively. The activity was tested at optimum 
$\mathrm{pH}(7.5)$ and temperature $\left(60^{\circ} \mathrm{C}\right)$. It was found that the peptidase activity was wholly inactivated by $\mathrm{Hg}^{+2}$. It has been reported that even trace amounts of heavy metals inactivate most peptidases, and $\mathrm{Hg}^{+2}$ is an inhibitor of thermolysin, which is a well-known metallopeptidase (Bankus \& Bond 2001). It was also observed that the metal ions $\mathrm{Cu}^{+2}, \mathrm{Ni}^{+2}$, and $\mathrm{Fe}^{+2}$ caused a substantial decrease in peptidase activity. Furthermore, the peptidase activity of PPPase was almost wholly inactivated in the presence of $5 \mathrm{mM} \mathrm{Fe}^{+3}$. Bankus \& Bond (2001) reported $\mathrm{Fe}^{+3}$ as an inhibitor of metallocarboxipeptidases. This information supports the idea that PPPase is a metallopeptidase-rich enzyme solution. Abdel-Naby et al. (2017) and Rehman et al. (2017) also observed a substantial inactivation in the enzyme activity in the presence of $\mathrm{Hg}^{+2}, \mathrm{Fe}^{+3}$ and $\mathrm{Cu}^{+2}$. In contrast to our study, Rehman et al. (2017) determined $\mathrm{Ni}^{+2}$ as a stimulator of B. subtilis KT004404 metallopeptidase activity.

It was determined in some studies that metallopeptidase activity increased by $7 \%$ (D'Costa $e t$ al. 2013), $17 \%$ (Sousa et al. 2007), $34 \%$ (Abdel-Naby et al. 2017), 94 \% (Manni et al. 2008), $200 \%$ (Manni et al. 2010) and even $4120 \%$ (Sharmila et al. 2018) in the presence of $\mathrm{Ca}^{+2}$ ions. It has been reported that $\mathrm{Ca}^{+2}$ ions stabilize thermolysin by preventing autolysis $(\mathrm{Wu} \&$ Chen 2011). However, in our study, it was observed that $\mathrm{Ca}^{+2}$ ions caused a decrease in peptidase activity, and also that increasing the concentration of $\mathrm{Ca}^{+2}$ ions resulted in the precipitation of peptidase. Similarly, Furhan et al. (2019) determined that $\mathrm{Ca}^{+2}$ ions caused a $57 \%$ decrease in the activity of cold-active metallopeptidase.

Among the metal ions, the most positive effect on peptidase activity was obtained with $\mathrm{Mn}^{+2}$ and $\mathrm{K}^{+1}$. It was determined that $5 \mathrm{mM}$ of $\mathrm{K}^{+1}$ and $5 \mathrm{mM}$ of $\mathrm{Mn}^{+2}$ ions increased the enzyme activity of PPPase by $4 \%$ and $6 \%$, respectively. In the presence of $\mathrm{Mn}^{+2}$ ions, a $178 \%$ increase (Lee et al. 2016) and a $17 \%$ decrease (Manni et al. 2008) in peptidase activity were determined.

Table 5. Effects of organic solvents and surfactants on enzyme activity at different concentrations (relative activity, \%).

\begin{tabular}{|c|c|c|c|c|}
\hline & & Concentration (\%) & CES & PPPase \\
\hline \multirow{12}{*}{ 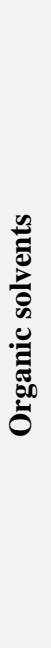 } & \multirow{3}{*}{ Xylene } & 1 & $86.25 \pm 0.15$ & $88.91 \pm 0.67$ \\
\hline & & 5 & $100.94 \pm 2.86$ & $97.88 \pm 1.00$ \\
\hline & & 20 & $102.81 \pm 0.29$ & $106.96 \pm 3.51$ \\
\hline & \multirow{3}{*}{ Acetone } & 1 & $110.62 \pm 0.15$ & $92.92 \pm 1.34$ \\
\hline & & 5 & $94.27 \pm 0.59$ & $93.04 \pm 1.17$ \\
\hline & & 20 & $103.02 \pm 3.83$ & $93.15 \pm 1.00$ \\
\hline & \multirow{3}{*}{ Ethanol } & 1 & $95.73 \pm 0.59$ & $86.78 \pm 0.00$ \\
\hline & & 5 & $111.46 \pm 0.44$ & $87.13 \pm 2.84$ \\
\hline & & 20 & $113.96 \pm 0.74$ & $85.72 \pm 0.83$ \\
\hline & \multirow{3}{*}{ Acetonitrile } & 1 & $122.60 \pm 0.88$ & $114.28 \pm 3.17$ \\
\hline & & 5 & $126.66 \pm 3.39$ & $105.31 \pm 0.15$ \\
\hline & & 20 & $62.09 \pm 0.74$ & $84.30 \pm 0.15$ \\
\hline \multirow{12}{*}{ 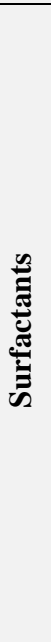 } & \multirow{3}{*}{ SDS } & 0.1 & $14.86 \pm 2.28$ & $0.03 \pm 0.00$ \\
\hline & & 0.5 & $6.86 \pm 1.48$ & $0.00 \pm 0.00$ \\
\hline & & 1 & $5.64 \pm 0.34$ & $0.00 \pm 0.00$ \\
\hline & \multirow{3}{*}{ Triton X-100 } & 0.1 & $108.55 \pm 3.09$ & $82.31 \pm 0.24$ \\
\hline & & 0.5 & $84.98 \pm 2.02$ & $67.07 \pm 1.07$ \\
\hline & & 1 & $81.66 \pm 0.00$ & $75.74 \pm 1.19$ \\
\hline & \multirow{3}{*}{ Tween 20} & 0.1 & $98.19 \pm 0.00$ & $79.28 \pm 0.48$ \\
\hline & & 0.5 & $116.63 \pm 2.69$ & $92.00 \pm 2.03$ \\
\hline & & 1 & $125.00 \pm 9.41$ & $100.67 \pm 1.43$ \\
\hline & \multirow{3}{*}{ Tween 80} & 0.1 & $122.62 \pm 9.01$ & $97.56 \pm 0.12$ \\
\hline & & 0.5 & $127.85 \pm 8.06$ & $106.74 \pm 0.71$ \\
\hline & & 1 & $129.08 \pm 3.63$ & $104.89 \pm 1.67$ \\
\hline
\end{tabular}

The peptidase activity was measured at optimum temperature $\left(60^{\circ} \mathrm{C}\right)$ and $\mathrm{pH}(7.5)$ after the enzyme solution and organic solvents or surfactants were mixed and kept at $37^{\circ} \mathrm{C}$ for $30 \mathrm{~min}$. 
Table 6. The effect of metal ions on enzyme activity (relative activity, \%).

\begin{tabular}{cccc|ccc}
\hline \hline & \multicolumn{3}{c}{ CES } & & \multicolumn{3}{c}{ PPPase } \\
\cline { 2 - 8 } Metal ions & $\mathbf{0 . 5} \mathbf{~ m M}$ & $\mathbf{2 ~} \mathbf{~ m M}$ & $\mathbf{5 ~ m M}$ & $\mathbf{0 . 5} \mathbf{~ m M}$ & $\mathbf{2 ~ m M}$ & $\mathbf{5} \mathbf{~ m M}$ \\
\hline \hline $\mathrm{Ca}^{+2}$ & $81.48 \pm 0.97$ & $86.39 \pm 1.98$ & $*$ & $87.63 \pm 0.73$ & $93.00 \pm 4.53$ & $87.36 \pm 0.36$ \\
$\mathrm{Co}^{+2}$ & $71.71 \pm 0.24$ & $73.72 \pm 3.17$ & $*$ & $96.22 \pm 1.21$ & $80.02 \pm 7.62$ & $74.80 \pm 0.38$ \\
$\mathrm{Cu}^{+2}$ & $77.37 \pm 0.48$ & $42.81 \pm 1.02$ & $36.91 \pm 0.33$ & $58.95 \pm 0.00$ & $56.61 \pm 3.03$ & $34.49 \pm 0.88$ \\
$\mathrm{Fe}^{+2}$ & $80.28 \pm 4.12$ & $69.31 \pm 0.69$ & $*$ & $72.69 \pm 0.97$ & $25.96 \pm 0.19$ & $53.96 \pm 0.50$ \\
$\mathrm{Fe}^{+3}$ & $70.51 \pm 0.48$ & $84.54 \pm 8.71$ & $*$ & $81.45 \pm 1.70$ & $19.55 \pm 5.09$ & $0.19 \pm 0.13$ \\
$\mathrm{Mg}^{+2}$ & $87.66 \pm 1.45$ & $95.16 \pm 1.50$ & $106.24 \pm 2.42$ & $96.57 \pm 0.73$ & $86.22 \pm 2.16$ & $93.46 \pm 0.55$ \\
$\mathrm{Hg}^{+2}$ & $4.32 \pm 0.48$ & $0.00 \pm 0.00$ & $0.00 \pm 0.00$ & $0.00 \pm 0.00$ & $0.00 \pm 0.00$ & $0.00 \pm 0.00$ \\
$\mathrm{Mn}^{+2}$ & $86.28 \pm 0.48$ & $78.25 \pm 0.73$ & $*$ & $92.96 \pm 1.94$ & $104.26 \pm 1.45$ & $106.15 \pm 4.70$ \\
$\mathrm{Zn}^{+2}$ & $68.79 \pm 1.94$ & $80.85 \pm 2.65$ & $*$ & $90.90 \pm 4.86$ & $91.01 \pm 0.63$ & $80.69 \pm 1.88$ \\
$\mathrm{Ni}^{+2}$ & $81.83 \pm 0.97$ & $32.47 \pm 8.69$ & $22.81 \pm 1.80$ & $65.65 \pm 2.67$ & $28.88 \pm 1.20$ & $14.30 \pm 0.48$ \\
$\mathrm{~K}^{+1}$ & $112.18 \pm 0.24$ & $92.54 \pm 4.27$ & $95.37 \pm 11.72$ & $102.92 \pm 0.97$ & $100.34 \pm 9.60$ & $104.42 \pm 2.71$ \\
$\mathrm{Na}^{+1}$ & $89.71 \pm 5.33$ & $94.73 \pm 0.77$ & $112.63 \pm 1.54$ & $94.85 \pm 1.70$ & $96.09 \pm 11.08$ & $98.10 \pm 2.26$ \\
\hline \hline
\end{tabular}

${ }^{*}$ Precipitation was observed when the enzyme was mixed with the metal ion (especially after incubation).

The activities of metal ion-free and 1:1 diluted CES and PPPase were $34.09 \mathrm{U} / \mathrm{ml}$ and $20.00 \mathrm{U} / \mathrm{ml}$, respectively.

Activity analyses were tested at optimum $\mathrm{pH}(7.5)$ and temperature $\left(60^{\circ} \mathrm{C}\right)$ after the enzyme solution and metal ions were mixed and kept at $37^{\circ} \mathrm{C}$ for $30 \mathrm{~min}$.

\section{Conclusions}

Characterization of the PPPase from $B$. amyloliquefaciens $\mathrm{FE}-\mathrm{K} 1$ reveals the enzyme as a neutral metallopeptidase compatible with some organic solvents and surfactants which are commonly used in detergents. Moreover, since the strain isolated from bread has previously been identified as a non-toxigenic organism, enzyme products obtained from the culturing of the strain may be used in the food industry. Using neutral and low thermotolerant enzymes have some advantages in food

\section{References}

1. Abdel-Naby, M.A., Ahmed, S.A., Wehaidy, H.R. \& ElMahdy, S.A. 2017. Catalytic, kinetic and thermodynamic properties of stabilized Bacillus stearothermophilus alkaline protease. International Journal of Biological Macromolecules, 96: 265-271.

2. Amal, K. \& Abdelouahab, N. 2017. Characterization of a milk-clotting enzyme produced by Bacillus mojavensis P47M strain isolated from Algerian dairy farm soil. Research Journal of Biotechnology, 12(12): 37-45.

3. Bailey, C.P. \& von Holy, A. 1993. Bacillus spore contamination associated with commercial bread manufacture. Food Microbiology, 10: 287-294.

4. Bankus, J.M. \& Bond, J.S. 2001. Appendix II- Some commercially available proteases. Pp. 295-316. In: Reynon, B. \& Bond, J.S. (eds) Proteolytic Enzymes. Oxford University Press, New York, 320 pp.

5. Bradford, M.M. 1976. A rapid and sensitive method for quantitation of microgram quantities of protein utilizing the principle of protein-dye binding. Analytical Biochemistry, 72: 248-254. industry, because it is easier to control them during food processing. Future studies will focus on utilizing the B. amyloliquefaciens FE-K1 peptidase for the modification of gluten proteins in flour to reduce the gluten content of bread.

\section{Acknowledgement}

This work was supported by the Scientific Research Projects Coordination Unit of Akdeniz University [project number 2010.03.0121.020].

6. Choi, J.H., Kim, J.E., Kim, S., Yoon, J., Park, D.H., Shin, H.J., Lee, H.J. \& Cho, S.S. 2017. Purification and partial characterization of a low molecular fibrinolytic serine metalloprotease $\mathrm{C} 142$ from the culture supernatant of Bacillus subtilis C142. International Journal of Biological Macromolecules, 104: 724-731.

7. Collins, N.E., Kirschner, L.A.M. \& von Holy, A. 1991. Characterization of Bacillus isolates from ropey bread, bakery equipment and raw materials. South African Journal of Science, 87: 62-66.

8. Contesini, F.J., Melo, R.R. \& Sato, H.H. 2018. An overview of Bacillus proteases: from production to application. Critical Reviews in Biotechnology, 38(3): 321-334.

9. Cupp-Enyard, C. 2008. Sigma's non-specific protease activity assay-casein as a substrate. Journal of Visualized Experiments, 19: 899.

10. da Silva, R.R. 2017. Bacterial and fungal proteolytic enzymes: production, catalysis and potential applications. Applied Biochemistry and Biotechnology, 183: 1-19. 
11. D’Costa, B., Khanolkar, D. \& Dubey, S.K. 2013. Partial purification and characterization of metalloprotease of halotolerant alkaliphilic bacterium Bacillus cereus from coastal sediment of Goa, India. African Journal of Biotechnology, 12(31): 4905-4914.

12. Doddapaneni, K.K., Tatineni, R., Vellanki, R.N., Rachcha, S., Anabrolu, N., Narakuti, V. \& Mangamoori, L.N. 2009. Purification and characterization of a solvent and detergentstable novel protease from Bacillus cereus. Microbiological Research, 164: 383-390.

13. Ellis, W.O., Obubuafo, A.K., Ofosu-Okyere, A., Marfo, E.K., Osei-Agyemang, K. \& Odame-Darkwah, J.K. 1997. A survey of bread defects in Ghana. Food Control, 8: 77-82.

14. Erem, F. \& Certel, M. 2018. Determination of peptidase production potential of Bacillus strains isolated from ropey bread and optimisation of some culture conditions for peptidase production. Anadolu University Journal of Science and Technology C-Life Sciences and Biotechnology, 7(2): 160-179.

15. Erem, F., Certel, M. \& Karakaş, B. 2009. Identification of Bacillus species isolated from ropey breads both with classical methods and API identification kits. Mediterranean Agricultural Sciences, 22(2): 201-210.

16. Erem, F., Inan, M. \& Certel, M. 2018. Optimisation of Bacillus amyloliquefaciens FE-K1 extracellular peptidase production by response surface methodology. Trakya University Journal of Natural Sciences, 19(2): 59-173.

17. Fernández-Resa, P., Mira, E. \& Quesada, R. 1994. Enhanced detection of casein zymography of matrix metalloproteinases. Analytical Biochemistry, 224: 434-435.

18. Furhan, J., Salaria, N., Jabeen, M. \& Qadri, J. 2019. Partial purification and characterisation of cold-active metalloprotease by Bacillus sp. AP1 from Apharwat peak, Kashmir. Pakistan Journal of Biotechnology, 16(1): 47-54.

19. Ghorbel, B., Sellami-Kamoun, A. \& Nasri, M. 2003. Stability studies of protease from Bacillus cereus BG1. Enzyme Microbiology and Technology, 32: 513-518.

20. Gupta, M.N. 1992. Enzyme function in organic solvents. European Journal of Biochemistry, 203: 25-32.

21. Gupta, R., Beg, Q.K., Khan, S. \& Chauhan, B. 2002a. An overview on fermentation, downstream processing and properties of microbial alkaline proteases. Applied Microbiology and Biotechnology, 60: 381-395.

22. Gupta, R., Beg, Q.K. \& Lorenz, P. 2002b. Bacterial alkaline proteases: molecular approaches and industrial applications. Applied Microbiology and Biotechnology, 59: 15-32.

23. Hammami, A., Bayoudh, A., Hadrich, B., Abdelhedi, O., Jridi, M. \& Nasri, M. 2020. Response-surface methodology for the production and the purification of a new $\mathrm{H} 2 \mathrm{O} 2$ tolerant alkaline protease from Bacillus invictae AH1 strain. Biotechnology Progress, e2965, doi: https://doi.org/10.1002/btpr.2965.

24. Iglesias, M.S., Sequeiros, C., García, S. \& Olivera, N.L. 2017. Newly isolated Bacillus sp. G51 from Patagonian wool produces an enzyme combination suitable for feltresist treatments of organic wool. Bioprocess and Biosystem Engineering, 40: 833-842.
25. Jisha, V.N., Smitha, R.B., Pradeep, S., Sreedevi, S., Unni, K.N., Sajith, S., Priji, P., Josh, M.S. \& Benjamin, S. 2013. Versatility of microbial proteases. Advances in Enzyme Research, 1(3): 39-51.

26. Kirschner, L.A.M. \& von Holy, A. 1989. Rope spoilage of bread. South African Journal of Science, 85: 425-427.

27. Kumar, C.G. \& Takagi, H. 1999. Microbial alkaline proteases: from a bioindustrial viewpoint. Biotechnology Advances, 17: 561-594.

28. Laemmli, U.K. 1970. Cleavage of structural proteins during the assembly of the head of bacteriophage T4. Nature, 227: 680-685.

29. Lauer, I., Bonnewitz, B., Meunier, A. \& Beverini, M. 2000. New approach for separating Bacillus subtilis metalloprotease and $\alpha$-amylase by affinity chromatography and for purifying neutral protease by hydrophobic chromatography. Journal of Chromatography B, 737: 277 284 .

30. Leber, T.M. \& Balkwill, F.R. 1997. Zymography: a singlestep staining method for quantitation of proteolytic activity on substrate gels. Analytical Biochemistry, 249: 24-28.

31. Lee, H., Suh, D.B., Hwang, J.H. \& Suh, H.J. 2002. Characterization of a keratinolytic metalloprotease from Bacillus sp. Applied Biochemistry and Biotechnology, 97: 123-133.

32. Lee, E.S., Lee, H.W., Lee, D.H. \& Kim, H. 2016. Characterization of a metalloprotease from an isolate Bacillus thuringiensis 29-126 in animal feces collected from a zoological garden in Japan. Journal of Applied Biological Chemistry, 59(4): 373-377.

33. Manni, L., Jellouli, K., Agrebi, R., Bayoudh, A. \& Nasri, M. 2008. Biochemical and molecular characterization of a novel calcium-dependent metalloprotease from Bacillus cereus SV1. Process Biochemistry, 43: 522-530.

34. Manni, L.-M., Jellouli, K., Ghorbel-Bellaaj, O., Agrebi, R., Sellami-Kamoun, A. \& Nasri, M. 2010. An oxidant- and solvent-stable protease produced by Bacillus cereus SV1: application in the deproteinization of shrimp wastes and as a laundry detergent additive. Applied Biochemistry and Biotechnology, 160: 2308-2321.

35. Mardina, V. \& Yusof, F. 2016. Purification and characterization of surfactant-stable protease from Bacillus licheniformis: A potential additive for laundry detergent. International Journal of Advanced Biotechnology and Research, 7(2): 634-643.

36. Maruthiah, T., Somanath, B., Immanuel, G. \& Palavesam, A. 2017. Investigation on production and purification of haloalkalophilic organic solvent tolerant protease from marine shell waste and its bioconversion to chitin by aquatic Bacillus sp. APCMST-CS4. Waste and Biomass Valorization, 8: 811-827.

37. Matta, H. \& Punj, V. 1998. Isolation and partial characterization of a thermostable extracellular protease of Bacillus polymyxa B-17. International Journal of Food Microbiology, 42: 139-145.

38. Mothe, T. \& Sultanpuram, V.R. 2016. Production, purification and characterization of a thermotolerant alkaline serine protease from a novel species Bacillus caseinilyticus. 3 Biotech, 6(53): 1-10. 
39. Pepe, O., Blaiotta, G., Moschetti, G., Greco, T. \& Villani, F. 2003. Rope-producing strains of Bacillus spp. from wheat bread and strategy for their control by lactic acid bacteria. Applied and Environmental Microbiology, 69(49): 2321-2329.

40. Qureshi, A.S., Simair, A.A., Ali, C.H., Khushk, I., Khokhar, J.A., Ahmad, A., Danish, M. \& Lu, C. 2018. Production, purification and partial characterization of organo-solvent tolerant protease from newly isolated Bacillus sp. BBXS-2. Fermentation Technology, 7(1): 151-159.

41. Rahman, R.N.Z.R.A., Mahamad, S., Salleh, A.B. \& Basri, M. 2007. A new organic solvent tolerant protease from Bacillus pumilus $115 \mathrm{~b}$. Journal of Industrial Microbiology and Biotechnology, 34: 509-517.

42. Rao, M.B., Tanksale. A.M., Ghatge, M.S. \& Deshpande, V.V. 1998. Molecular and biotechnological aspects of microbial proteases. Microbiology and Molecular Biology Reviews, 62(3): 597-635.

43. Rawlings, N.D., Morton, F.R. \& Barrett, A.J. 2007. An introduction to peptidases and the Merops database. Pp. 161-179. In: Polaina, J. \& MacCabe, A. (eds) Industrial enzymes-structure, function and applications. Springer, The Netherlands, xii $+641 \mathrm{pp}$.

44. Razzaq, A., Shamsi, S., Ali, A., Ali, Q., Sajjad, M., Malik, A. \&Ashraf, M. 2019. Microbial Proteases Applications. Frontiers in Bioengineering and Biotechnology, 7: 110129.

45. Rehman, R., Ahmed, M., Siddique, A., Hasan, F., Hameed, A. \& Jamal, A. 2017. Catalytic role of thermostable metalloproteases from Bacillus subtilis KT004404 as dehairing and destaining agent. Applied Biochemistry and Biotechnology, 181(1): 434-450.

46. Rosenkvist, H. \& Hansen, A. 1995. Contamination profiles and characterization of Bacillus species in wheat bread and raw materials for bread production. International Journal of Food Microbiology, 26: 353-363.

47. Sabirova, A.R., Rudakova, N.L., Balaban, N.P., Ilyinskaya, O.P., Demidyuk, I.V., Kostrov, S.V., Rudenskaya, G.N. \& Sharipova, M.R. 2010. A novel secreted metzincin metalloproteinase from Bacillus intermedius. FEBS Letters, 584: 4419-4425.

48. Salleh, A.B., Razak, C.N.A., Rahman, R.N.Z.R.A. \& Basri, M. 2006. Protease: introduction. Pp. 23-39. In: Salleh, A.B., Razak, C.N.A. \& Basri, M. (eds) New lipases and proteases. Nova Science Publishers, New York, 159 pp.

49. Salwan, R. \& Sharma, V. 2019. Trends in extracellular serine proteases of bacteria as detergent bioadditive: alternate and environmental friendly tool for detergent industry. Archives of Microbiology, 201: 863-877.

50. Sandhya, C., Nampoothiri, K.M. \& Pandey, A. 2005. Microbial proteases, Pp. 165-179. In: Barredo, J.L. (ed)
Microbial enzymes and biotransformations, Humana Press, Totowa, $\mathrm{xi}+319 \mathrm{pp}$.

51. Schallmey, M., Singh, A. \& Ward, O.P. 2004. Developments in the use of Bacillus species for industrial production. Canadian Journal of Microbiology, 50: 1-17.

52. Sharmila, G.R., Halami, P.M. \& Venkateswaran, G. 2018. Identification and characterization of a calcium dependent bacillopeptidase from Bacillus subtilis CFR5 with novel kunitz trypsin inhibitor degradation activity. Food Research International, 103: 263-272.

53. Si, J.B., Jang, E.J., Charalampopoulos, D. \& Wee, Y.J. 2018. Purification and characterization of microbial protease produced extracellularly from Bacillus subtilis FBL-1. Biotechnology and Bioprocess Engineering, 23(2): 176-182.

54. Sousa, F., Jus, S., Erbel, A., Kokol, V., Cavco-Paulo, A. \& Gubitz, G.M. 2007. A novel metalloprotease from Bacillus cereus for protein fibre processing. Enzyme and Microbial Technology, 40: 1772-1781.

55. Thapa, S., Li, H., OHair, J., Bhatti, S., Chen, F.C., Nasr, K.A., Johnson, T. \& Zhou, S. 2019. Biochemical characteristics of microbial enzymes and their significance from industrial perspectives. Molecular Biotechnology, 61: 579-601.

56. Thompson, J.M., Dodd, C.E.R. \& Waites, W.M. 1993 Spoilage of bread by Bacillus. International Biodeterioration and Biodegradation, 32: 55-66.

57. Thompson, J.M., Waites, W.M. \& Dodd, C.E.R. 1998. Detection of rope spoilage in bread caused by Bacillus species. Journal of Applied Microbiology, 85: 481-486.

58. Tian, J., Long, X., Tian, Y. \& Shi, B. 2019. Eco-friendly enzymatic dehairing of goatskins utilizing a metalloprotease high-effectively expressed by Bacillus subtilis SCK6. Journal of Cleaner Production, 212: 647-654.

59. Volavsek, P.J.A., Kirschner, L.A.M. \& von Holy, A. 1992. Accelerated methods to predict the rope-inducing potential of bread raw materials. South African Journal of Science, 88: 99-102.

60. Voysey, P.A. 1989. Rope: a problem for bakers. Journal of Applied Bacteriology, 67: 25-26.

61. Waites, M.J., Morgan, N.L., Rockey, J.S., and Higton, G. 2001. Industrial microbiology: an introduction. Blackwell, London, 288 pp.

62. Wang, S.L., Kao, T.Y., Wang, C.L., Yen, Y.H., Chern, M.K. \& Chen, Y.H. 2006. A solvent stable metalloprotease produced by Bacillus sp. TKU004 and its application in the deproteinization of squid pen for $\beta$-chitin preparation. Enzyme Microbiology and Technology, 39: 724-731.

63. Wu, J.W. \& Chen, X.L. 2011. Extracellular metalloproteases from bacteria. Applied Microbiology and Biotechnology, 92: 253-262. 